\title{
Antimicrobial Properties of Plant Essential Oils against Human Pathogens and Their Mode of Action: An Updated Review
}

\author{
Mallappa Kumara Swamy, ${ }^{1,2}$ Mohd Sayeed Akhtar, ${ }^{3}$ and Uma Rani Sinniah ${ }^{1}$ \\ ${ }^{1}$ Department of Crop Science, Faculty of Agriculture, Universiti Putra Malaysia, 43400 Serdang, Selangor, Malaysia \\ ${ }^{2}$ Padmashree Institute of Management and Sciences, Kommagatta, Kengeri, Bangalore 560060, India \\ ${ }^{3}$ Department of Botany, Gandhi Faiz-E-Aam College, Shahjahanpur, Uttar Pradesh 242001, India
}

Correspondence should be addressed to Mallappa Kumara Swamy; swamy.bio@gmail.com, Mohd Sayeed Akhtar; sayeedbot@gmail.com, and Uma Rani Sinniah; umarani@upm.edu.my

Received 14 July 2016; Revised 10 September 2016; Accepted 9 October 2016

Academic Editor: Pinarosa Avato

Copyright ( 2016 Mallappa Kumara Swamy et al. This is an open access article distributed under the Creative Commons Attribution License, which permits unrestricted use, distribution, and reproduction in any medium, provided the original work is properly cited.

\begin{abstract}
A wide range of medicinal and aromatic plants (MAPs) have been explored for their essential oils in the past few decades. Essential oils are complex volatile compounds, synthesized naturally in different plant parts during the process of secondary metabolism. Essential oils have great potential in the field of biomedicine as they effectively destroy several bacterial, fungal, and viral pathogens. The presence of different types of aldehydes, phenolics, terpenes, and other antimicrobial compounds means that the essential oils are effective against a diverse range of pathogens. The reactivity of essential oil depends upon the nature, composition, and orientation of its functional groups. The aim of this article is to review the antimicrobial potential of essential oils secreted from MAPs and their possible mechanisms of action against human pathogens. This comprehensive review will benefit researchers who wish to explore the potential of essential oils in the development of novel broad-spectrum key molecules against a broad range of drug-resistant pathogenic microbes.
\end{abstract}

\section{Introduction}

Medicinal and aromatic plants (MAPs) constitute a large part of natural flora and are considered an important resource in various fields such as the pharmaceutical, flavor and fragrance, perfumery, and cosmetic industries [1]. At present, more than $80 \%$ of the global population depends on traditional plant-based medications for treating various human health problems [2-4]. According to an estimate, the worth of herbal products on the global market is approximately 62 billion USD, and it is predicted to grow up to 5 trillion USD by the year 2050 [5]. More than 9000 native plants have been identified and recorded for their curative properties, and about 1500 species are known for their aroma and flavor. Essential-oil-based products or natural aroma chemicals are in higher demand in the cosmetic, food, perfume, and pharmaceutical industries, and more than 250 types of essential oils, at a value of 1.2 billion USD, are traded annually on the international market $[3,6]$.
Essential oils obtained from MAPs are aromatic in nature because of a mixture of multifarious chemical substances that belong to different chemical families, including terpenes, aldehydes, alcohols, esters, phenolic, ethers, and ketones [3, 7]. Essential oils have tremendous business potential on the global market owing to their unique flavor and fragrance properties and also biological activities [6, 8]. Essential oils are employed in aromatherapy and for the treatment of several diseases including cardiovascular disease, diabetes, Alzheimer's, cancer [9]. The antimicrobial impacts of essential oils and their chemical components have been recognized by several researchers in the past $[3,10-13]$. Furthermore, studies have shown the synergistic effect of any two or more ingredients of essential oils against various human pathogens $[14,15]$.

More recently, the prevalence of antimicrobial drug resistance has prompted researchers to discover novel antimicrobial lead molecules to treat various human pathogens [16]. Some of the presently available synthetic drugs fail to inhibit 
many pathogenic microbes. In addition, the use of synthetic chemicals for the control of pathogenic microorganisms is limited because of their carcinogenic effects, acute toxicity, and environmental hazard potential. In this regard, the exploitation of essential oils to control epidemic multidrugresistant pathogenic microorganisms can be useful to combat various infectious diseases [17]. Therefore, the present review details the antibacterial, antifungal, and antiviral potentials of essential oils extracted from MAPs as well as their therapeutic relevance and possible mechanisms involved in the reticence of human pathogenic microorganisms. In addition, this review suggests avenues for more research studies on essential oils to be used against drug-resistant microbial pathogens.

\section{Chemical Composition of Essential Oils}

Essential oils have the ability to hamper the growth of a diverse range of pathogens because of the presence of natural compounds produced by the organs of plants. Importantly, the unique aroma and other bioactive properties of an essential oil depend on its chemical constituents. In MAPs, essential oils generally accumulate in the secretary canals or cavities and glandular trichomes and sometimes in the epidermal cells [4]. Essential oils and their chemical constituents exhibit more bioactivity when present in the oxygenated or active form. In general, the chemical composition of essential oils is relatively complex, and about 20 to 60 different bioactive components are observed in many of these essential oils. Many of these compounds are pharmaceutically appreciated for their numerous culinary properties $[1,4,7$, 13]. Usually, the chemical characterization of many essential oils reveals the presence of only 2-3 major components at a fairly high concentration (20-70\%) compared to other components present in trace amounts [101]. Most essential oils are composed of terpenes, terpenoids, and other aromatic and aliphatic constituents with low molecular weights. Terpenes or terpenoids are synthesized within the cytoplasm of the cell through the mevalonic acid pathway [15]. Terpenes are composed of isoprene units and are generally represented by the chemical formula $\left(\mathrm{C}_{5} \mathrm{H}_{8}\right)_{n}$. Terpenes can be acyclic, monocyclic, bicyclic, or tricyclic [102]. Owing to the diversity in their chemical structures, terpenes are classified into several groups such as monoterpenes $\left(\mathrm{C}_{10} \mathrm{H}_{16}\right)$, sesquiterpenes $\left(\mathrm{C}_{15} \mathrm{H}_{24}\right)$, diterpenes $\left(\mathrm{C}_{20} \mathrm{H}_{32}\right)$, and triterpenes $\left(\mathrm{C}_{30} \mathrm{H}_{40}\right)$. The major component $(\sim 90 \%)$ of bioactive essential oils is constituted of monoterpenes [103]. Some of the major compounds include monoterpene hydrocarbons ( $p$-cymene, limonene, $\alpha$-pinene, and $\alpha$-terpinene), oxygenated monoterpenes (camphor, carvacrol, eugenol, and thymol), diterpenes (cembrene $\mathrm{C}$, kaurene, and camphorene), sesquiterpene hydrocarbons ( $\beta$-caryophyllene, germacrene $\mathrm{D}$, and humulene), oxygenated sesquiterpenes (spathulenol, caryophyllene oxide), monoterpene alcohols (geraniol, linalool, and nerol), sesquiterpene alcohol (patchoulol), aldehydes (citral, cuminal), acids (geranic acid, benzoic acid), ketones (acetophenone, benzophenone), lactones (bergapten), phenols (eugenol, thymol, carvacrol, and catechol), esters (bornyl acetate, ethyl acetate), and coumarins (fumarin, benzofuran) $[1,4,8,13,104,105]$. The structures of some of these compounds are represented in Figure 1. The major and biologically important chemical constituents of MAPs are shown in Tables 1, 2, and 3 .

The chemical constituents of plant essential oils differ between species. Some factors that can affect these constituents include the geographical location, environment, and stage of maturity $[4,106]$. This chemical difference is directly related to differences in antimicrobial activities against various pathogenic microorganisms [107]. For example, the major chemical constituents of origanum essential oil (carvacrol and thymol) were shown to differ in their origin as well as antimicrobial property.

Furthermore, the stereochemical properties of essential oils can vary and depend upon the method of extraction [108]. However, extraction products may also vary qualitatively and quantitatively in their composition [109]. Although essential oils can be recovered using fermentation, extraction, or effleurage processes, commercial production is preferably achieved by the steam distillation process $[1,4,110]$. Likewise, the antimicrobial efficiency of essential oils depends on the type of microbes to be inhibited as well as the evaluation methods, including bioautography, diffusion, and dilution $[111,112]$. Methods to evaluate the essential oil chemistry, their biological activities, and various factors that affect bioactivity are detailed in the literature $[110,112,113]$.

\section{Antimicrobial Effects of Essential Oils}

The antimicrobial effects of essential oils derived from MAPs are the basis of copious applications, in various revenue generating sectors such as pharmaceutical, nutraceutical, cosmetic, perfume, agronomy, and sanitary industries [1-3]. In the following section, we have broadly discussed the antibacterial, antifungal, and antiviral effects of essential oils obtained from MAPs.

3.1. Antibacterial Effects of Essential Oils. At present, many antibiotics are available for treating various bacterial pathogens. However, increased multidrug resistance has led to the increased severity of diseases caused by bacterial pathogens. In addition, low immunity in host cells and the ability of bacteria to develop biofilm-associated drug resistance have further increased the number of lifethreatening bacterial infections in humans [114]. Thus, bacterial infections remain a major causative agent of human death, even today. In addition, the use of several antibacterial agents at higher doses may cause toxicity in humans. This has prompted researchers to explore alternative new key molecules against bacterial strains [115]. In this regard, plant essential oils and their major chemical constituents are potential candidates as antibacterial agents. Several types of essential oils and their major chemical constituents from various MAPs have been reported to possess a wide range of bacterial inhibitory potentials (Table 1).

The effect of antibacterial activity of essential oils may inhibit the growth of bacteria (bacteriostatic) or destroy bacterial cells (bactericidal). Nevertheless, it is difficult to distinguish these actions. In relation to this, antibacterial 
TABLE 1: Chemical composition of various essential oils and their antibacterial activity against human pathogens.

\begin{tabular}{|c|c|c|c|c|}
\hline MAPs & Part used & Major chemical compounds & Inhibited microorganisms & References \\
\hline Achillea clavennae & Leaves and flowers & $\begin{array}{l}\text { Camphor, myrcene, } 1,8 \text {-cineole, } \\
\beta \text {-caryophyllene, linalool, geranyl acetate }\end{array}$ & $\begin{array}{l}\text { Klebsiella pneumonia, } \\
\text { Streptococcus pneumonia, } \\
\text { Haemophilus influenzae, } \\
\text { Pseudomonas aeruginosa }\end{array}$ & {$[18]$} \\
\hline $\begin{array}{l}\text { Achillea } \\
\text { fragrantissima }\end{array}$ & Aerial parts & $\begin{array}{l}\text { Yomogi alcohol, 1,8-cineole, artemisia alcohol, } \\
\text { thujone }\end{array}$ & $\begin{array}{c}\text { Staphylococcus aureus, } \\
\text { Staphylococcus epidermidis, } \\
\text { Escherichia coli }\end{array}$ & {$[19]$} \\
\hline Achillea ligustica & Aerial parts & Viridiflorol, terpinen-4-ol & Streptococcus mutans & {$[20]$} \\
\hline $\begin{array}{l}\text { Artemisia } \\
\text { absinthium }\end{array}$ & Aerial parts & Myrcene, trans-thujone, trans-sabinyl acetate & $\begin{array}{c}\text { E. coli, S. aureus, } \\
\text { Staphylococcus epidermidis }\end{array}$ & {$[21]$} \\
\hline Artemisia biennis & Aerial parts & $\begin{array}{l}(Z) \text {-Beta-ocimene, }(E) \text {-beta-farnesene, } \\
\text { acetylenes, }(Z) \text { - and }(E) \text {-En-yn-dicycloethers }\end{array}$ & $\begin{array}{l}\text { E. coli, } S \text {. aureus, } S \text {. } \\
\text { epidermidis }\end{array}$ & {$[21]$} \\
\hline Artemisia cana & Aerial parts & Santolina triene, alpha-pinene, camphene & $\begin{array}{l}\text { E. coli, S. aureus, } S . \\
\text { epidermidis }\end{array}$ & {$[21]$} \\
\hline $\begin{array}{l}\text { Artemisia } \\
\text { dracunculus }\end{array}$ & Aerial parts & $\begin{array}{l}\text { Methylchavicol, methyl eugenol, } \\
\text { beta-phellandrene, terpinolene }\end{array}$ & $\begin{array}{c}\text { E. coli, S. aureus, S. } \\
\text { epidermidis, Brochothrix } \\
\text { thermosphacta, Listeria } \\
\text { innocua, L. monocytogenes, } \\
\text { Pseudomonas putida, } \\
\text { Shewanella putrefaciens }\end{array}$ & {$[21,22]$} \\
\hline Artemisia longifolia & Aerial parts & Alpha-pinene, camphene, 1,8-cineole & $\begin{array}{l}\text { E. coli, } S . \text { aureus, } S . \\
\text { epidermidis }\end{array}$ & {$[21]$} \\
\hline Artemisia frigida & Aerial parts & 1,8-Cineole, methylchavicol, camphor & $\begin{array}{l}\text { E. coli, S. aureus, } S . \\
\text { epidermidis }\end{array}$ & {$[21]$} \\
\hline
\end{tabular}

Enterobacteriaceae, $S$. aureus, Streptococcus pyogenes, S. pneumoniae, Enterococcus faecalis, E. faecium, Bacillus cereus, Acinetobacter lwoffi, Cinnamomum $\quad$ Bark, leaves $\quad$ Cinnamaldehyde
zeylancium Enterobacter aerogenes, $E$. coli, Klebsiella pneumoniae,

Proteus mirabilis, $P$. aeruginosa, Salmonella typhimurium, Clostridium perfringens,

Mycobacterium smegmatis

\begin{tabular}{c} 
Copaifera officinalis $\quad \begin{array}{c}\beta \text {-Caryophyllene, } \beta \text {-bisabolene, germacrene B, } \\
\alpha \text {-copaene, germacrene } \mathrm{D}, \alpha \text {-humulene, } \\
\delta \text {-cadinene }\end{array}$ \\
\hline
\end{tabular}

\begin{tabular}{lcc}
\hline Coriandrum sativum & Leaves & 2E-Decenal, decanal, 2E-decen-1-ol, n-decanol \\
\hline Cuminum cyminum & Leaves & $\gamma$-Terpin-7-al, $\gamma$-terpinene, $\beta$-pinene, \\
cuminaldehyde
\end{tabular}

S. aureus, Bacillus spp., E. coli, Salmonella typhi, $K$. pneumonia, Proteus mirabilis, $P$. aeruginosa

S. typhimurium, E. coli

Enterobacteriaceae, $S$. aureus

Brochothrix thermosphacta,

Cymbopogon nardus $\quad$ Leaves, stems $\quad \Delta$ 2-Carene, beta-citronellal

E. coli, Listeria innocua, $L$. monocytogenes, P. putida,

S. typhimurium, $S$. putrefaciens

S. aureus, $L$.

monocytogenes, $L$.

Cyperus longus

Arial part

$\beta$-Himachalene, $\alpha$-humulene, $\gamma$-himachalene monocytogenes, E. faecium,

S. Enteritidis, E. coli, $P$. aeruginosa 
TABle 1: Continued.

\begin{tabular}{|c|c|c|c|c|}
\hline MAPs & Part used & Major chemical compounds & Inhibited microorganisms & References \\
\hline Daucus littoralis & $\begin{array}{l}\text { Leaves, stems, roots, } \\
\text { flowers, fruits }\end{array}$ & Germacrene D, acorenone B & S. aureus, E. coli & {$[31]$} \\
\hline $\begin{array}{l}\text { Dracocephalum } \\
\text { foetidum }\end{array}$ & Leaves & $\begin{array}{c}\text { n-Mentha-1,8-dien-10-al, limonene, geranial, } \\
\text { neral }\end{array}$ & $\begin{array}{l}\text { B. subtilis, S. aureus, } \\
\text { M.luteus, E. hirae, S. } \\
\quad \text { mutans, E. coli }\end{array}$ & {$[32]$} \\
\hline $\begin{array}{l}\text { Eremanthus } \\
\text { erythropapps }\end{array}$ & Leaves & $\begin{array}{l}\text { (Z)-Caryophyllene, germacrene D, viridiflorol, } \\
\text { p-cymene, } \gamma \text {-terpinene }\end{array}$ & S. epidermidis & {$[33]$} \\
\hline $\begin{array}{l}\text { Eugenia } \\
\text { caryophyllata } \\
\end{array}$ & Flower buds & $\begin{array}{l}\text { Phenylpropanoids such as carvacrol, thymol, } \\
\text { eugenol, cinnamaldehyde }\end{array}$ & S. epidermidis & {$[34]$} \\
\hline $\begin{array}{l}\text { Euphrasia } \\
\text { rostkoviana }\end{array}$ & Essential oil & $\begin{array}{l}\text { n-Hexadecanoic acid, thymol, myristic acid, } \\
\text { linalool }\end{array}$ & $\begin{array}{c}\text { E. faecalis, E. coli, } K . \\
\text { pneumoniae, S. aureus, } S . \\
\text { epidermidis, } P \text {. aeruginosa }\end{array}$ & {$[35]$} \\
\hline Foeniculum vulgare & Leaves & Trans-anethole, methylchavicol, limonene & S. typhimurium, E. coli & {$[28]$} \\
\hline Fortunella margarita & Leaves & Gurjunene, eudesmol, muurolene & $\begin{array}{c}\text { B. subtilis, S. aureus, } \\
\text { Sarcina luta, } S \text {. faecalis, E. } \\
\text { coli, K. pneumonia, } P . \\
\text { aeruginosa }\end{array}$ & {$[36]$} \\
\hline Juniperus phoenicea & Arial part & $\alpha$-Pinene, $\beta$-phellandrene, $\alpha$-terpinyl acetate & $\begin{array}{c}\text { S. aureus, } L . \\
\text { monocytogenes, } L . \\
\text { monocytogenes, } E \text {. faecium, } \\
\text { S. Enteritidis, } E \text {. coli, } P . \\
\text { aeruginosa }\end{array}$ & {$[30]$} \\
\hline Laurus nobilis & Arial part & Eucalyptol (1,8-cineole), linalool & $\begin{array}{l}\text { Mycobacterium smegmatis, } \\
\text { E. coli }\end{array}$ & {$[37]$} \\
\hline $\begin{array}{l}\text { Lavandula } x \\
\text { intermedia } \\
\text { "Provence" (Blue } \\
\text { Lavandin) (a cross } \\
\text { between L. } \\
\text { angustifolia, L. } \\
\text { Latifolia) }\end{array}$ & Arial part & $\begin{array}{l}\text { Camphor, eucalyptol (1,8-cineole), linalool, } \\
\beta \text {-pinene, } \alpha \text {-pinene }\end{array}$ & M. smegmatis, E. coli & [37] \\
\hline Juniperus excelsa & Leaves and twigs & $\alpha$-Pinene, $\alpha$-cedrol, $\delta$-car-3-ene & S. aureus & {$[38]$} \\
\hline Lippia sidoides & Leaves & Thymol and carvacrol & $\begin{array}{l}\text { S. mutans, } S . \text { sanguis, } S \text {. } \\
\text { salivarius, } S \text {. mitis }\end{array}$ & {$[39]$} \\
\hline Mentha piperita & Arial part & & $\begin{array}{l}\text { S. aureus, } S . \text { typhimurium, } \\
\text { V. parahaemolyticus }\end{array}$ & {$[40]$} \\
\hline Mentha pulegium & Arial part & Piperitone, piperitenone, $\alpha$-terpineol, pulegone & $\begin{array}{l}\text { S. aureus, S. epidermidis, } B . \\
\text { cereus, L. monocytogenes, } \\
\text { E. coli, S. typhimurium, V. } \\
\text { cholera, L. monocytogenes, } \\
\text { E. faecium, S. Enteritidis }\end{array}$ & {$[30]$} \\
\hline Mentha suaveolens & Arial part & $\begin{array}{l}\text { Pulegone, piperitone, cis-cis-p-menthenolide, } \\
\text { limonene germacrene }\end{array}$ & $\begin{array}{l}\text { Lactococcus lactis subsp. } \\
\text { Lactis, S. xylosus }\end{array}$ & {$[41]$} \\
\hline $\begin{array}{l}\text { Melaleuca } \\
\text { alternifolia (tea tree } \\
\text { oil) }\end{array}$ & Essential oil & $\begin{array}{l}\text { Terpinen-4-ol, } 1,8 \text {-cineole, } \gamma \text {-terpinene, } \\
\alpha \text {-terpinene, terpinolene }\end{array}$ & $\begin{array}{l}\text { E. coli, } S \text {. aureus, } S . \\
\text { epidermidis, E. faecalis, } P \text {. } \\
\text { aeruginosa, } \text { M. avium, } H \text {. } \\
\text { influenzae, } S \text {. pyogenes, } S \text {. } \\
\quad \text { pneumonia }\end{array}$ & {$[42,43]$} \\
\hline $\begin{array}{l}\text { Momordica } \\
\text { charantia }\end{array}$ & Seed & $\begin{array}{c}\text { Trans-nerolidol, apiole, cis-dihydrocarve,ol } \\
\text { germacrene D }\end{array}$ & E. coli, S. aureus & {$[44]$} \\
\hline Myrtus communis & Leaves & Eugenol, $\alpha$-terpineol, $\gamma$-terpinene & $\begin{array}{c}\text { S. aureus, } L \text {. } \\
\text { monocytogenes, E. durans, } \\
\text { Salmonella Typhi, E. coli, } B \text {. } \\
\text { subtilis, } \text { M. tuberculosis, } P \text {. } \\
\text { aeruginosa, K. pneumonia, } \\
\text { M. avium subsp. } \\
\text { paratuberculosis, E. cloacae }\end{array}$ & {$[30,45]$} \\
\hline Nigella sativa & Seeds & $\begin{array}{l}\text { Thymoquinone, } p \text {-cymene, } \alpha \text {-thujene, } \\
\text { thymohydroquinone, longifolene }\end{array}$ & $\begin{array}{l}\text { S. aureus, B. cereus, E. coli, } \\
\text { P. aeruginosa }\end{array}$ & {$[46]$} \\
\hline
\end{tabular}


TABle 1: Continued.

Limonene, $\delta$-3-carene, $\alpha$-pinene,

$\beta$-caryophyllene, $\beta$-pinene, sabinene,

Piper nigrum Essential oil $\begin{gathered}\alpha \text {-felandeno, myrcene, para-cymene, linalool, } \\ \text { terpinolene, } \beta \text {-selinene, } 1,8 \text { cineole, }\end{gathered} \quad$ S. aureus, E. coli

$\alpha$-terpinene, $\alpha$-humulene, $\alpha$-copaene, eugenol,

terpinen-4-ol, camphene, safrole

\begin{tabular}{|c|c|c|c|c|}
\hline Pimpinella anisum & Seed & Trans-anethole & S. typhimurium, E. coli & {$[58]$} \\
\hline $\begin{array}{l}\text { Plectranthus } \\
\text { barbatus }\end{array}$ & Leaves & $\begin{array}{l}\text { (Z)-Caryophyllene, germacrene D, viridiflorol, } \\
\text { p-cymene, } \gamma \text {-terpinene }\end{array}$ & S. epidermidis & {$[4,33]$} \\
\hline P. amboinicus & Leaves & $\begin{array}{l}\text { (Z)-Caryophyllene, germacrene D, viridiflorol, } \\
\text { p-cymene, } \gamma \text {-terpinene }\end{array}$ & S. epidermidis & {$[4,33]$} \\
\hline $\begin{array}{l}\text { Plectranthus } \\
\text { neochilus }\end{array}$ & Leaves & $\begin{array}{c}\alpha \text {-Pinene, } \beta \text {-pinene, trans-caryophyllene, } \\
\text { caryophyllene oxide }\end{array}$ & $\begin{array}{l}\text { E. faecalis, S. salivarius, } S . \\
\text { sobrinus, S. sanguinis, } S . \\
\text { mitis, L. casei, S. mutans }\end{array}$ & {$[4,59]$} \\
\hline Pogostemon cablin & Leaves & $\begin{array}{l}\text { Patchoulol, } \delta \text {-guaieno; gurjunene- } \alpha, \alpha \text {-guaiene, } \\
\text { aromadendrene, } \beta \text {-patchoulene }\end{array}$ & $\begin{array}{l}\text { K. pneumonia, } H . \text { pylori, } E . \\
\text { coli, B. subtilis, } S . \text { aureus, } P . \\
\text { aeruginosa, E. faecalis }\end{array}$ & {$[1,60-64]$} \\
\hline $\begin{array}{l}\text { Rosmarinus } \\
\text { officinalis }\end{array}$ & Leaves, flower & $\begin{array}{l}\text { Camphor, camphene, limonene, geraniol, } \\
\text { myrcene, linalool benzoylacetate, linalool, } \\
\alpha \text {-pinene, } \alpha \text {-terpinolene, bornyl acetate, } \\
\text { borneol }\end{array}$ & $\begin{array}{l}\text { E. coli, S. typhimurium, } B . \\
\text { cereus, Bacillus subtilis, } S . \\
\text { aureus, S. agalactiae, } S . \\
\text { epidermidis, S. aureus, } P \text {. } \\
\text { vulgaris, } P \text {. aeruginosa, } K . \\
\text { pneumonia, E. faecalis, } B . \\
\text { thermosphacta, L. innocua, } \\
\text { L. monocytogenes, } P . \\
\text { putida, } S . \text { typhimurium, } S \text {. } \\
\text { putrefaciens, M. smegmatis }\end{array}$ & $\begin{array}{c}{[22,37,65,} \\
66]\end{array}$ \\
\hline Satureja hortensis & Arial part & Carvacrol, thymol, $\gamma$-terpinene & $\begin{array}{l}\text { C. botulinum, } C . \\
\text { perfringens, }\end{array}$ & [49] \\
\hline
\end{tabular}


TABle 1: Continued.

\begin{tabular}{|c|c|c|c|c|}
\hline MAPs & Part used & Major chemical compounds & Inhibited microorganisms & References \\
\hline Salvia sclarea & Arial part & $\begin{array}{l}\text { Linalool, linalyl acetate, geranyl acetate, } \beta \text { - } \\
\text { ocimene acetate, caryophyllene oxide }\end{array}$ & $\begin{array}{c}\text { S. aureus, } S . \text { agalactiae, } S . \\
\text { epidermis, E. coli, Proteus } \\
\text { vulgaris, } P \text {. aeruginosa, } K . \\
\text { pneumonia, E. faecalis, } B . \\
\text { pumilus, } B . \text { subtilis, } S . \\
\text { typhimurium }\end{array}$ & {$[67-70]$} \\
\hline Salvia officinalis & Arial part & $\alpha$-Thujone, camphor, 1,8 -cineole, $\alpha$-pinene & $\begin{array}{c}\text { S. aureus, } P \text {. stuartii, } P . \\
\text { stuartii, E. coli, Shigella } \\
\text { sonnei, Sarcina lutea, } M . \\
\text { flavus, B. thermosphacta, E. } \\
\text { coli, L. innocua, } L . \\
\text { monocytogenes }\end{array}$ & {$[17,22,70]$} \\
\hline Salvia lavandulifolia & Essential oil & $\begin{array}{c}\text { Camphor, } \alpha \text {-thujone, beta-thujone, camphene, } \\
\alpha \text {-pinene, terpineol }\end{array}$ & $\begin{array}{l}\text { P. vulgaris, } P \text {. aeruginosa, } \\
\text { K. pneumonia, E. faecalis }\end{array}$ & {$[68,70]$} \\
\hline Satureja cuneifolia & Aerial parts & Carvacrol and $p$-cymene & $\begin{array}{c}\text { E. coli, Campylobacter } \\
\text { jejuni, S. sonnei, S. aureus, } \\
\text { L. monocytogenes, } B . \\
\text { cereus, } \text { P. aeruginosa, } S . \\
\text { enteritidis }\end{array}$ & {$[71]$} \\
\hline $\begin{array}{l}\text { Struchium } \\
\text { sparganophora }\end{array}$ & Leaves & $\begin{array}{l}\beta \text {-Caryophyllene, germacrene A, } \alpha \text {-humulene, } \\
\text { germacrene D }\end{array}$ & $\begin{array}{c}\text { S. typhi, } B \text {. cereus, } P \text {. } \\
\text { mirabilis, } P \text {. aeruginosa, } B . \\
\text { subtilis }\end{array}$ & {$[72]$} \\
\hline $\begin{array}{l}\text { Syzygium } \\
\text { aromaticum }\end{array}$ & Leaves, flower bud & Eugenol, eugenylacetate & $\begin{array}{c}\text { P. aeruginosa, } \\
\text { Enterobacteriaceae }\end{array}$ & {$[22,25]$} \\
\hline Syzygium cumini & Leaves & $\begin{array}{c}\alpha \text {-Pinene, } \beta \text {-pinene, trans- caryophyllene, } \\
\text { 1,3,6-octatriene, delta- } 3 \text {-carene, } \\
\alpha \text {-caryophyllene, } \alpha \text {-limonene }\end{array}$ & $\begin{array}{c}\text { E. coli, } S \text {. aureus, } P \text {. } \\
\text { aeruginosa, } N \text {. } \\
\text { gonorrhoeae, } B . \text { subtilis, } S \text {. } \\
\text { aureus }\end{array}$ & [73] \\
\hline $\begin{array}{l}\text { Trachyspermum } \\
\text { ammi }\end{array}$ & Seeds & - & $\begin{array}{l}\text { K. pneumoniae, E. coli, } S . \\
\text { aureus }\end{array}$ & {$[74]$} \\
\hline Thymus vulgaris & Arial part & $\begin{array}{l}\text { Thymol, linalool, carvacrol, } 1,8 \text {-cineole, } \\
\text { eugenol, camphor, camphene, } \alpha \text {-pinene, } \\
\text { borneol, } \beta \text {-pinene }\end{array}$ & $\begin{array}{l}\text { L. monocytogenes, E. coli,S. } \\
\text { typhimurium, S. aureus, C. } \\
\text { botulinum, C. perfringens, } \\
\text { S. sonnei, S. lutea, M. } \\
\text { flavus, B. thermosphacta, L. } \\
\text { innocua, L. monocytogenes, } \\
\text { P. putida, S. putrefaciens }\end{array}$ & $\begin{array}{l}{[22,40,49} \\
53,54,75 \\
76]\end{array}$ \\
\hline Thymus zygis & Essential oil & - & $\begin{array}{l}\text { S. choleraesuis, } S \text {. } \\
\text { typhimurium, E. coli }\end{array}$ & {$[50]$} \\
\hline Thymus mastichina & Leaves, stems & m-Thymol, carvacrol, trans-caryophyllene & $\begin{array}{l}\text { B. thermosphacta, E. coli, } L . \\
\text { innocua, L. monocytogenes, } \\
\text { P. putida, S. typhimurium, } \\
\text { S. putrefaciens }\end{array}$ & [22] \\
\hline Thymus kotschyanus & Arial part & $\begin{array}{l}\text { Carvacrol, 1,8 cineole, thymol, borneol, } \\
\text { E-caryophyllene }\end{array}$ & $\begin{array}{l}\text { S. aureus, } \text { S. epidermidis, } B . \\
\text { cereus, E. coli }\end{array}$ & [77] \\
\hline $\begin{array}{l}\text { Thuja sp. (Thuja } \\
\text { plicata, Thuja } \\
\text { occidentalis) }\end{array}$ & Essential oil & Alpha-thujone and beta-thujone & $\begin{array}{c}\text { P. aeruginosa, } K . \\
\text { pneumoniae, } S . \text { aureus, } E . \\
\text { coli }\end{array}$ & {$[68]$} \\
\hline Verbena officinalis & Arial part & Borneol, geranoil & $\begin{array}{l}\text { S. aureus, E. coli, } S \text {. } \\
\text { typhimurium, } L . \\
\text { monocytogenes }\end{array}$ & [78] \\
\hline Warionia saharae & Arial part & $\begin{array}{l}\beta \text {-Eudesmol, trans-nerolidol, linalool, } 1,8 \\
\text { cineole, camphor, } p \text {-cymene, terpinen- } 4 \text {-ol }\end{array}$ & $\begin{array}{l}\text { S. aureus, } B \text {. cereus, } P \text {. } \\
\text { aeruginosa, E. coli }\end{array}$ & [79] \\
\hline
\end{tabular}

activity is more frequently measured as the minimum bactericidal concentration $(\mathrm{MBC})$ or the minimum inhibitory concentration (MIC) [110]. Rapid antibacterial screening of essential oils is usually conducted using the agar diffusion technique, where essential oils are added to filter paper discs or holes, which are put in agar that has been uniformly inoculated with a bacterial strain. After incubating, the inhibition zone represents the antimicrobial action [111]. 
TABLE 2: Chemical composition of various essential oils and their antifungal activity against human pathogens.

\begin{tabular}{|c|c|c|c|c|}
\hline MAPs & Part used & Major chemical compounds & Inhibited microorganisms & References \\
\hline Aegle marmelos & Leaves & $\begin{array}{c}\gamma \text {-Cadinene, } \delta \text {-carene, } \\
\alpha \text {-pinene }\end{array}$ & $\begin{array}{c}\text { Candida albicans, Aspergillus niger, Fusarium } \\
\text { oxysporum }\end{array}$ & {$[36]$} \\
\hline Artemisia biennis & Aerial parts & $\begin{array}{l}(Z) \text { - } \beta \text {-Ocimene, } \\
(E) \text {-beta-farnesene, } \\
\text { acetylenes, }(Z) \text { - and } \\
(E) \text {-en-yn-dicycloethers }\end{array}$ & $\begin{array}{c}\text { Cryptococcus neoformans, Fonsecaea pedrosoi, } A . \\
\text { niger }\end{array}$ & [21] \\
\hline $\begin{array}{l}\text { Cinnamomum } \\
\text { zeylancium }\end{array}$ & Bark, leaves & Cinnamaldehyde & C. albicans, C. parapsilosis, C. krusei & {$[23,24]$} \\
\hline Coriandrum sativum & Leaves & $\begin{array}{l}\text { 2E-Decenal, decanal, } \\
\text { 2E-decen-1-ol, n-decanol }\end{array}$ & C. albicans & {$[26,27]$} \\
\hline Daucus littoralis & $\begin{array}{l}\text { Leaves, stems, } \\
\text { roots, flowers, } \\
\text { fruits } \\
\end{array}$ & Germacrene D, acorenone B & C. albicans & {$[80]$} \\
\hline $\begin{array}{l}\text { Dracocephalum } \\
\text { foetidum }\end{array}$ & Leaves & $\begin{array}{l}\text { n-Mentha-1,8-dien-10-al, } \\
\text { limonene, geranial, neral }\end{array}$ & C. albicans & [32] \\
\hline $\begin{array}{l}\text { Eremanthus } \\
\text { erythropappus }\end{array}$ & Leaves & $\begin{array}{l}\text { (Z)-Caryophyllene, } \\
\text { germacrene } \mathrm{D} \text {, viridiflorol, } \\
\text { p-cymene, } \gamma \text {-terpinene }\end{array}$ & $\begin{array}{c}\text { C. albicans, C. gattii, C. gattii, C. neoformans, } S . \\
\text { cerevisiae }\end{array}$ & [33] \\
\hline Euphrasia rostkoviana & Essential oil & $\begin{array}{l}\text { n-Hexadecanoic acid, thymol, } \\
\text { myristic acid, linalool }\end{array}$ & C. albicans & {$[35]$} \\
\hline Feoniculum vulgare & Seed & $\begin{array}{l}\text { Trans-anethole, } \\
\text { methylchavicol, limonene }\end{array}$ & Alternaria alternata, F. oxysporum, A. flavus & {$[81]$} \\
\hline Fortunella margarita & Leaves & $\begin{array}{c}\text { Gurjunene, eudesmol, } \\
\text { muurolene }\end{array}$ & A. niger, C. albicans & {$[36]$} \\
\hline Glechon spathulata & Leaves & $\begin{array}{l}\beta \text {-Caryophyllene, } \\
\text { bicyclogermacrene }\end{array}$ & Trichophyton rubrum, Epidermophyton floccosum & {$[82]$} \\
\hline Glechon marifolia & Leaves & $\begin{array}{l}\beta \text {-Caryophyllene, } \\
\text { bicyclogermacrene }\end{array}$ & T. rubrum, E. floccosum & {$[82]$} \\
\hline Lippia sidoides & Leaves & Thymol and carvacrol & C. albicans & [39] \\
\hline $\begin{array}{l}\text { Melaleuca alternifolia } \\
\text { (tea tree oil) }\end{array}$ & Essential oil & $\begin{array}{l}\text { Terpinen- } 4 \text {-ol, } 1,8 \text {-cineole, } \\
\gamma \text {-terpinene, } \alpha \text {-terpinene, } \\
\text { terpinolene }\end{array}$ & $\begin{array}{l}\text { Alternaria spp. A. flavus, A. fumigates, A. niger, } \\
\text { Blastoschizomyces Capitatus, C. albicans, C. } \\
\text { glabrata, C. parapsilosis, C. tropicalis, } \\
\text { Cladosporium spp., C. neoformans, } \\
\text { Epidermophyton floccosum, Fusarium spp., } \\
\text { Malassezia furfur, Microsporum canis, M. } \\
\text { sympodialis, M. gypseum, Penicillium spp., } \\
\text { Rhodotorula rubra, Saccharomyces cerevisiae, } \\
\text { Trichophyton mentagrophytes, T. rubrum, T. } \\
\text { tonsurans, Trichosporon spp. } \\
\end{array}$ & $\begin{array}{l}{[42,81,83,} \\
84]\end{array}$ \\
\hline Mentha pulegium & Arial part & $\begin{array}{l}\text { Piperitone, piperitenone, } \\
\alpha \text {-terpineol pulegone }\end{array}$ & $\begin{array}{c}\text { A. niger, C. albicans, C. zemplinina, Kloeckera } \\
\text { apiculata, Metschnikowia pulcherrima, } \\
\text { Tetrapisispora phaffi }\end{array}$ & {$[30,41]$} \\
\hline Momordica charantia & Seed & $\begin{array}{l}\text { Trans-nerolidol, apiole, } \\
\text { cis-dihydrocarveol, } \\
\text { germacrene D }\end{array}$ & C. albicans & {$[44]$} \\
\hline Myrtus communis & Leaves & $\begin{array}{c}\text { Eugenol, } \alpha \text {-terpineol, } \\
\gamma \text {-terpinene, } \alpha \text {-caryophyllene }\end{array}$ & C. albicans, A. flavus & {$[45,85-87]$} \\
\hline Nigella sativa & Seeds & $\begin{array}{l}\text { Thymoquinone, } p \text {-cymene, } \\
\alpha \text {-thujene, } \\
\text { thymohydroquinone, } \\
\text { longifolene }\end{array}$ & $\begin{array}{c}\text { A. flavus, Fusarium moniliforme, F. graminearum, } \\
\text { P. viridicatum }\end{array}$ & {$[46,62]$} \\
\hline $\begin{array}{l}\text { Ocimum species } \\
\text { (Ocimum basilicum, } \\
\text { Ocimum gratissimum, } \\
\text { O. kilimandscharicum, } \\
\text { O. lamiifolium, } O . \\
\text { suave) }\end{array}$ & Leaves, flower & $\begin{array}{l}\text { Eugenol, methyl eugenol, } \\
\text { cis-ocimene, trans-ocimene, } \\
\alpha \text {-pinene camphor }\end{array}$ & $\begin{array}{l}\text { C. albicans, C. tropicalis, C. glabrata, } P \text {. notatum, } R \text {. } \\
\text { stolonifer, M. mucedo, A. ochraceus, A. versicolor, } \\
\text { A. niger, A. fumigates, T. viride, P. funiculosum }\end{array}$ & $\begin{array}{l}{[26,27,47} \\
\quad 48,57]\end{array}$ \\
\hline
\end{tabular}


TABle 2: Continued.

\begin{tabular}{|c|c|c|c|c|}
\hline MAPs & Part used & Major chemical compounds & Inhibited microorganisms & References \\
\hline Origanum vulgare & Leaves, arial part & $\begin{array}{c}\text { Carvacrol, thymol, } \\
\gamma \text {-terpinene, trans-sabinene } \\
\text { hydrate, cis-piperitol, borneol, } \\
\text { terpinen-4-ol, linalool }\end{array}$ & $\begin{array}{l}\text { C. albicans, A. niger, M. gypseum, M. canis, } A \text {. } \\
\text { cajetani, T. violaceum, T. mentagrophytes, E. } \\
\text { floccosum, T. rubrum, T. tonsurans, } \\
\text { phytopathogens B. cinerea and P. oryzae }\end{array}$ & {$[52,56,88]$} \\
\hline $\begin{array}{l}\text { Pelargonium } \\
\text { graveolens }\end{array}$ & Leaves & $\begin{array}{l}\text { Citronellol, citronellyl } \\
\text { formate, geraniol }\end{array}$ & C. tropicalis & [89] \\
\hline $\begin{array}{l}\text { Plectranthus barbatus } \\
\text { and P. amboinicus }\end{array}$ & Leaves & $\begin{array}{l}\text { (Z)-Caryophyllene, } \\
\text { germacrene } \mathrm{D} \text {, viridiflorol, } \\
\text { p-cymene, } \gamma \text {-terpinene }\end{array}$ & $\begin{array}{c}\text { C. albicans, C. gattii, C. gattii, C. neoformans, } S . \\
\text { cerevisiae. }\end{array}$ & {$[4,33]$} \\
\hline Pogostemon cablin & Leaves & $\begin{array}{l}\text { Patchoulol, } \delta \text {-guaieno; } \\
\text { gurjunene- } \alpha, \alpha \text {-guaiene, } \\
\text { aromadendrene, } \\
\beta \text {-patchoulene }\end{array}$ & Aspergillus species, C. albicans & {$[1,90,91]$} \\
\hline Rosmarinus officinalis & Leaves & $\begin{array}{c}\text { Camphor, camphene, } \\
\text { limonene, geraniol, myrcene, } \\
\text { linalool benzaylacetate, } \\
\text { linalool, } \alpha \text {-pinene, } \\
\alpha \text {-terpinolene, bornyl acetate, } \\
\text { borneol }\end{array}$ & $\begin{array}{c}\text { C. albicans, } \text { M. gypseum, } M \text {. canis, A. cajetani, } T . \\
\text { violaceum, T. mentagrophytes, E. floccosum, } T . \\
\text { rubrum, T. tonsurans, phytopathogens B. cinerea, } P . \\
\text { oryzae }\end{array}$ & {$[65,88]$} \\
\hline Salvia sclarea & Arial part & $\begin{array}{c}\text { Linalool, linalyl acetate, } \\
\text { geranyl acetate, } \beta \text { - ocimene } \\
\text { acetate, caryophyllene oxide }\end{array}$ & $\begin{array}{c}\text { C. albicans, C. tropicalis, C. krusei, C. glabrata, C. } \\
\text { parapsilosis }\end{array}$ & {$[39,84]$} \\
\hline Syzygium aromaticum & Leaves & Eugenol, eugenylacetate & A. fumigatus, C. albicans, Candida spp. & {$[25,92]$} \\
\hline
\end{tabular}

TABLE 3: Chemical composition of various essential oils and their antiviral activity against human pathogens.

\begin{tabular}{|c|c|c|c|c|}
\hline Plant & Part used & Chemical compounds & Inhibited microorganisms & References \\
\hline $\begin{array}{l}\text { Achillea } \\
\text { fragrantissima }\end{array}$ & Aerial parts & $\begin{array}{l}\text { 2,5,5-Trimethyl-3,6- } \\
\text { heptadien-2-ol, eucalyptol, } \\
\text { artemisia alcohol, thujone }\end{array}$ & ORF virus (a parapox virus) & {$[19]$} \\
\hline $\begin{array}{l}\text { Artemisia } \\
\text { arborescens }\end{array}$ & Aerial parts & $\begin{array}{l}\beta \text {-Thujone, linalool, } \\
\text { myrcene, carvacrol }\end{array}$ & $\begin{array}{l}\text { Herpes simplex virus type } 1 \\
\text { (HSV-1) }\end{array}$ & {$[93]$} \\
\hline $\begin{array}{l}\text { Fortunella } \\
\text { margarita }\end{array}$ & Leaves & $\begin{array}{l}\text { Gurjunene, eudesmol, } \\
\text { muurolene }\end{array}$ & $\begin{array}{l}\text { Avian influenza A virus } \\
\text { (H5N1), }\end{array}$ & {$[94]$} \\
\hline Glechon spathulata & Leaves & $\begin{array}{l}\beta \text {-Caryophyllene, } \\
\text { bicyclogermacrene }\end{array}$ & HSV-1 & {$[82]$} \\
\hline Glechon marifolia & Leaves & $\begin{array}{l}\beta \text {-Caryophyllene, } \\
\text { bicyclogermacrene }\end{array}$ & HSV-1 & {$[82]$} \\
\hline Hyptis mutabilis & Leaves & $\begin{array}{c}\alpha \text {-Phellandrene, } p \text {-cymene, } \\
\text { E-caryophyllene }\end{array}$ & HSV-1 & {$[95]$} \\
\hline $\begin{array}{l}\text { Lepechinia } \\
\text { salviifolia }\end{array}$ & Leaves & Germacrene D & HSV-1 & {$[95]$} \\
\hline Melissa officinalis & Leaves & $\begin{array}{c}\text { Myrcene, linalool, } \\
\text { camphor, citronellal, } \\
\beta \text {-caryophyllene, } \\
\text { caryophyllene oxide, citral }\end{array}$ & $\begin{array}{l}\text { HSV-2, avian influenza } \\
\text { virus (AIV) subtype H9N2 }\end{array}$ & {$[19,96]$} \\
\hline $\begin{array}{l}\text { Minthostachys } \\
\text { mollis }\end{array}$ & Leaves & $\alpha$-Pinene, estragole & HSV-1 & {$[95]$} \\
\hline $\begin{array}{l}\text { Ocimum } \\
\text { campechianum }\end{array}$ & Leaves & Linalool, eugenol & HSV-1 & {$[95]$} \\
\hline Pogostemon cablin & Leaves & $\begin{array}{l}\text { Patchoulol, } \delta \text {-guaieno; } \\
\text { gurjunene- } \alpha, \alpha \text {-guaiene, } \\
\text { aromadendrene, } \\
\beta \text {-patchoulene }\end{array}$ & Influenza A (H2N2) virus & {$[1,97-99]$} \\
\hline $\begin{array}{l}\text { Trachyspermum } \\
\text { ammi }\end{array}$ & Leaves & $\begin{array}{l}\text { Thymol, } \alpha \text {-pinene, } \\
p \text {-cymene, limonene }\end{array}$ & $\begin{array}{c}\text { Japanese encephalitis virus } \\
\text { (JEV) }\end{array}$ & {$[100]$} \\
\hline
\end{tabular}



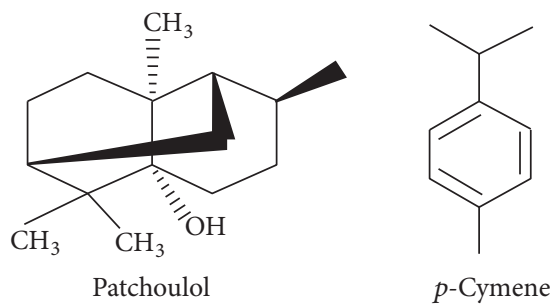

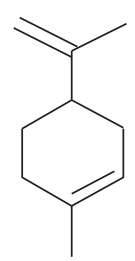

Limonene<smiles>Cc1cc(O)c(C(=O)CCC(C)C)c(=O)o1</smiles>

Pogostone<smiles>C=C1C=CC(CCC(C)=CCCC(C)C)CC1</smiles>

Germacrene D<smiles>C=C1CCC=C(C)CC[C@]2(C)C(C)(C)C[C@]12C</smiles>

Caryophyllene

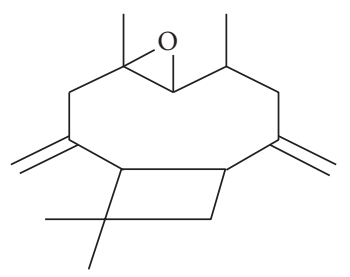

Caryophyllene oxide

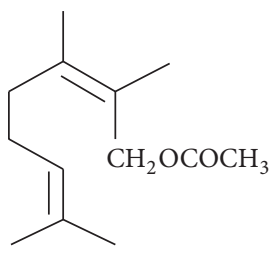

Geranyl acetate<smiles>C=CCCC(C)=CCO</smiles>

Geraniol<smiles>C=CCc1ccc(O)c(OC)c1</smiles>

Eugenol<smiles>Cc1ccc(C(C)C)cc1O</smiles>

Carvacrol<smiles>Cc1ccc(C(C)C)c(O)c1C</smiles>

Thymol

FIgURE 1: Structures of some important chemical compounds of essential oils.

The effectiveness of essential oils differs from one type to another as well as against different target bacteria depending on their structure (Gram-positive and Gram-negative bacteria). For instance, sandalwood and vetiver oils exhibit higher inhibitory activity against Gram-positive bacteria; however, they fail to inhibit Gram-negative bacterial strains $[83,114]$. The essential oils of cinnamon, clove, pimento, thyme, oregano, and rosemary were shown to possess strong antibacterial activity against Salmonella typhi, Staphylococcus aureus, and Pseudomonas aeruginosa [116]. Clove oil was found to be the most effective among all the tested essential oils. The antimicrobial effect of these oils was correlated to the occurrence of the major compounds such as carvacrol, thymol, cinnamic aldehyde, eugenol, and p-cymene. Likewise, carvacrol, eugenol, and thymol obtained from MAPs have been shown to effectively inhibit food-borne pathogens such as Escherichia coli, Salmonella typhimurium, Listeria monocytogenes, and Vibrio vulnificus [117]. The compounds such as benzoic acids, benzaldehydes, and cinnamic acid have shown up to $50 \%$ inhibition of Listeria monocytogenes under anaerobic conditions [118]. Ouattara et al. [119] reported the antibacterial potential of clove, cinnamon, pimento, and rosemary essential oils against meat spoilage bacterial pathogens such as Pseudomonas fluorescens, Serratia liquefaciens, Brochothrix thermosphacta, Carnobacterium piscicola, Lactobacillus curvatus, and Lactobacillus sake. According to them, the 1/100 dilution of these essential oils was capable of inhibiting at least 5-6 of the tested microbes. The inhibitory effect of these oils was mainly correlated with the occurrence of eugenol and cinnamaldehyde in the essential oils. Other major compounds found were carvacrol, thymol, cinnamaldehyde, and camphor. Arora and Kaur [120] analyzed the antimicrobial activity of garlic, ginger, clove, black pepper, and green chilli on human pathogenic bacteria such as Bacillus sphaericus, Enterobacter aerogenes, E. coli, Pseudomonas aeruginosa, S. aureus, Staphylococcus epidermidis, S. typhi, and Shigella flexneri. They concluded that, among all these spices, the aqueous extract of garlic was sensitive against all the tested bacterial pathogens. The garlic extract inhibited $93 \%$ of S. epidermidis and S. typhi within $3 \mathrm{~h}$ of incubation time. Similarly, the effect of clove extracts on the production of verotoxin by $E$. coli was studied by Sakagami et al. [121], who found that verotoxin production was inhibited by the clove extract (MIC value of $>1.0 \% \mathrm{w} / \mathrm{v}$ ). The effectiveness of cardamom, anise, basil, coriander, rosemary, parsley, dill, and angelica essential oils against pathogenic and saprophytic microorganisms was examined by Elgayyar et al. [58]. They concluded that essential oils extracted from oregano, basil, and coriander plants have an inhibitory effect against $P$. aeruginosa, $S$. aureus, and Yersinia enterocolitica in the range of $400 \mathrm{ppm}$ concentration. Skandamis et al. [122] observed the significance of oregano essential oils on the behavior of $S$. typhimurium in sterile and naturally contaminated beef fillets stored under aerobic and customized atmospheric conditions. The addition of oregano essential oils $(0.8 \% \mathrm{v} / \mathrm{w})$ reduced the majority of the tested bacterial pathogens. Hood et al. [23] reported that the bacterial growth may be suppressed by the ample use 
of essential oils or their use at high concentrations and that their mode of action results in the decline of bacterial cells. In another study, Achillea clavennae essential oil exhibited maximum inhibitory activity against respiratory diseasecausing microbes like Klebsiella pneumoniae, Streptococcus pneumoniae, Haemophilus influenzae, and P. aeruginosa [18]. The oil contained eucalyptol (1,8-cineole) and camphor as major compounds. According to Nevas et al. [49], pathogenic bacteria such as Clostridium botulinum and Clostridium perfringens were effectively inhibited by oregano, savory, and thyme essential oils. The major compounds with an antibacterial effect were found to be camphor, thymol, and carvacrol. The essential oil of Salvia officinalis contains $\alpha$-thujone, camphor, and 1,8-cineole as the major chemical constituents and was shown to inhibit human bacterial pathogens such as S. aureus and Providencia stuartii [67]. Some pathogenic bacteria (Salmonella choleraesuis, Salmonella enteritidis, S. typhimurium, and E. coli) were inhibited by the essential oils of thyme and oregano [50]. The essential oils showed an MIC value of $0.25 \%$ to $\geq 2 \%$ v/v. In another study, Salvia spp. ( $S$. officinalis, S. sclarea, and S. lavandulifolia) and Thuja spp. (T. plicata and T. occidentalis) essential oils exhibited potent antimicrobial properties against human pathogens [68]. The major components ( $\alpha$-thujone and $\beta$-thujone) of these sage species demonstrated high inhibitory activity against $P$. aeruginosa and K. pneumoniae, whereas S. aureus and E. coli were moderately inhibited.

The antibacterial activity of oregano oil against $S$. aureus, Bacillus subtilis, E. coli, and P. aeruginosa was reported by Santoyo et al. [51]. The MBC values ranged between 0.75 and $2.25 \mathrm{mg} / \mathrm{mL}$. Carvacrol was the most effective compound with an MBC value of 0.75 to $1.53 \mathrm{mg} / \mathrm{mL}$, followed by linalool with 1.04 to $1.75 \mathrm{mg} / \mathrm{mL}$. Similarly, oregano essential oil was also shown to be effective against Providencia stuartii and E. coli [52]. The essential oils of Thuja spp. (T. plicata and T. occidentalis) effectively inhibited $P$. aeruginosa, K. pneumoniae, S. aureus, and E. coli [68]. Moreover, Chaieb et al. [34] revealed the antimicrobial potential of the essential oil of Eugenia caryophyllata against numerous multidrug-resistant S. epidermidis strains isolated from dialysis biomaterials. Saet et al. [32] reported the presence of $n$-mentha-1,8-dien-10al, limonene, geranial, and neral as the major constituents in Dracocephalum foetidum essential oil. The oil exhibited antibacterial activity against human pathogenic bacteria such as S. aureus, B. subtilis, Enterococcus hirae, E. coli, Micrococcus luteus, Streptococcus mutans, and Saccharomyces cerevisiae. The MIC value ranged from 26 to $2592 \mu \mathrm{g} / \mathrm{mL}$. Likewise, Botelho et al. [39] reported the antibacterial activity of Lippia sidoides oil against four strains of cariogenic bacteria, namely, Streptococcus sanguis, S. mutans, Streptococcus salivarius, and Streptococcus mitis. The MIC value ranged from 0.625 to $10.0 \mathrm{mg} / \mathrm{mL}$. Lopes-Lutz et al. [21] reported that several species of Artemisia essential oil possessed strong activity against E. coli, S. aureus, and S. epidermidis. Likewise, Momordica charantia seed essential oil exhibited inhibitory action against $E$. coli and $S$. aureus with an MIC value of $>500$ and $125 \mu \mathrm{g} / \mathrm{mL}$, respectively [44]. The medicinal plant Achillea ligustica containing terpinen-4-ol, $\beta$-pinene, 1,8-cineole, and linalool showed effective inhibitory activity against S. mutans with an MIC ranging from 155 to $625 \mu \mathrm{g} / \mathrm{mL}$ [20]. Many food-borne and spoilage bacterial pathogens were inhibited by Satureja cuneifolia essential oil and the MIC values were in the range of $600-1400 \mu \mathrm{g} / \mathrm{mL}$ [71]. The essential oil of Coriandrum sativum demonstrated an antimicrobial potential against a wide range of bacterial pathogens, but the highest inhibition was found against Bacillus cereus and E. coli. The MIC of oil for Grampositive bacteria was observed to be $108 \mathrm{mg} / \mathrm{mL}$ and, for Gram-negative bacteria, it ranged from 130 to $217 \mathrm{mg} / \mathrm{mL}$ [26]. Moreover, the essential oils extracted from thyme and mint leaves exhibited antibacterial activity against the $S$. aureus, S. typhimurium, Vibrio parahaemolyticus, L. monocytogenes, E. coli, C. botulinum, C. perfringens, Shigella sonnei, Sarcinalutea, and Micrococcusflavus [40, 75]. The Gramnegative bacterial strains showed more sensitivity towards the thyme oil. The MIC value ranged from 0.33 to $2.67 \mathrm{mg} / \mathrm{mL}$ [75]. The essential oil of Myrtus communis was reported to inhibit various bacterial strains such as $S$. aureus, L. monocytogenes, Enterococcus durans, S. typhi, Enterobacter cloacae, E. coli, B. subtilis, Mycobacterium tuberculosis, P. aeruginosa, K. pneumoniae, and Mycobacterium avium [85, 123]. Similarly, Unlu et al. [24] reported that diverse range of bacterial pathogens such as S. aureus, Streptococcus pyogenes, S. pneumoniae, Enterococcus faecalis, Enterococcus faecium, B. cereus, Acinetobacter lwoffii, E. aerogenes, E. coli, K. pneumoniae, Proteus mirabilis, P. aeruginosa, S. typhimurium, C. perfringens, and Mycobacterium smegmatis were inhibited by the essential oil of Cinnamomum zeylancium. In a study by Shan et al. [78], the essential oils of cinnamon, oregano, clove, pomegranate peels, and grape seeds were found to be effective against $S$. enterica, but the clove extracts possessed the highest antibacterial activity. Melaleuca alternifolia (tea tree oil) and its major constituent, terpinen-4-ol, were shown to possess potential antibacterial properties against many pathogens including E. coli, S. aureus, S. epidermidis, E. faecalis, $P$. aeruginosa, M. avium, $H$. influenzae, S. pyogenes, and $S$. pneumoniae. Overall, it was shown that tea tree oil and terpinen-4-ol have limited influence on the development of antibacterial resistance and susceptibility [42]. AitOuazzou et al. [30] studied the essential oil composition and antibacterial potential of Mentha pulegium, Juniperus phoenicea, and Cyperus longus and concluded that all these oils were effective against food-borne pathogens ( $S$. aureus, L. monocytogenes, E. faecium, S. Enteritidis, E. coli, and P. aeruginosa). According to them, $M$. pulegium exhibited the best antibacterial activity compared to $J$. phoenicea and $C$. longus. The MIC value of $M$. pulegium oil was $<0.5$ for $E$. faecium and $1 \mu \mathrm{L} / \mathrm{mL}$ for $S$. aureus, L. monocytogenes, $E$. coli, and S. enteritidis. Lawal et al. [124] have reported the antibacterial activity of essential oil of Ocimum gratissimum, O. kilimandscharicum, O. lamiifolium, and O. suave against $S$. aureus, Bacillus sp., E. coli, P. aeruginosa, S. typhi, K. pneumoniae, and $P$. mirabilis. The MIC values varied between 1.25 and $10 \mathrm{mg} / \mathrm{mL}$ (flower oil) and between 0.16 and $10 \mathrm{mg} / \mathrm{mL}$ (leaf oil). The thyme oil obtained from leaves showed the presence of camphor, camphene, $\alpha$-pinene, 1,8 -cineole, borneol, and $\beta$ pinene, which exhibited effective antibacterial activity against S. aureus, S. epidermidis, Streptococcus sp., Pantoa sp., and 
E. coli $[53,76]$. The thyme oil showed MIC and MBC values of $627.7 \mu \mathrm{g} / \mathrm{mL}$ and $990.2 \mu \mathrm{g} / \mathrm{mL}$, respectively, against the $E$. coli strain. The major compound thymol showed MIC and MBC values of $2786 \mu \mathrm{g} / \mathrm{mL}$ and $2540 \mu \mathrm{g} / \mathrm{mL}$, respectively. Therefore, this study proposes the possible use of thyme oil as a potential antimicrobial agent for food preservation [76]. The oil obtained from Laurus nobilis and Lavandula intermedia showed inhibitory potential against Mycobacterium smegmatis and E. coli [37]. The bacterial strains (Shigella sonnei, Sarcina lutea, and Micrococcus flavus) were inhibited by the essential oil of Origanum vulgare [54]. The zone of inhibition and MIC values of $O$. vulgare oil were in the range of 9-36 mm and 125-600 $\mu \mathrm{g} / \mathrm{mL}$, respectively. Several food-borne pathogens such as Brochothrix thermosphacta, E. coli, Listeria innocua, L. monocytogenes, Pseudomonas putida, S. typhimurium, and Shewanella putrefaciens were inhibited by some commercial essential oils including those of Ocimum basilicum, Petroselinum sativum, and Rosmarinus officinalis [22]. The essential oil of Syzygium cumini was found to contain $\alpha$-pinene, $\beta$-pinene, trans-caryophyllene, $1,3,6$ octatriene, delta-3-carene, $\alpha$-caryophyllene, and limonene as major chemical compounds and possessed effective antibacterial activity against pathogenic bacterial strains such as $E$. coli, S. aureus, P. aeruginosa, Neisseria gonorrhoeae, B. subtilis, and S. aureus [73]. The essential oil exhibited moderate inhibition zones (12-14 mm) against the tested microbes. Andrade et al. [25] studied the antimicrobial activity of 27 different essential oils employed in aromatherapy procedures and found that Piper nigrum, Melaleuca alternifolia, Copaifera officinalis, and Cinnamomum cassia essential oils were effective against $S$. aureus and E. coli, whereas $S$. aromaticum essential oil was efficient against $P$. aeruginosa strains. Khoury et al. [38] have reported that Juniperus excelsa essential oil obtained from leaves and twigs was efficient at inhibiting S. aureus (MIC value of $64 \mathrm{mg} / \mathrm{ml}$ ) and Trichophyton rubrum (MIC value of $128 \mathrm{mg} / \mathrm{mL}$ ). Although the essential oil of Mentha suaveolens showed strong antibacterial activity against $S$. $x y$ losus with an MIC value of $14.4 \mu \mathrm{L} / \mathrm{mL}$, it showed no activity against lactic acid bacterial strains except Lactococcus lactis [41]. The essential oil of the herb Struchium sparganophora revealed the presence of $\beta$-caryophyllene, germacrene $\mathrm{A}, \alpha$-humulene, and germacrene $\mathrm{D}$ as major chemical constituents and it exhibited antibacterial activity against S. typhi, B. cereus, B. subtilis, P. mirabilis, and $P$. aeruginosa [72]. The inhibitory zone for leaf oil ranged from $9.0 \pm 1.0$ to $14.3 \pm 2.55 \mathrm{~mm}$, whereas the essential oil from stem had inhibitory activity ranging from $18.5 \pm 2.2$ to $20.0 \pm 0.0 \mathrm{~mm}$. Daucus littoralis oil obtained from different parts of the plant has showed a strong antibacterial activity against $E$. coli and $S$. aureus with an MIC value ranging from 20 to $40 \mu \mathrm{L} / \mathrm{mL}$ [31]. Likewise, Beatovic et al. [57] have reported the antibacterial activity of Ocimum basilicum oil against $S$. typhimurium and E. coli. The MIC values ranged between 0.009 and $23.48 \mu \mathrm{g} / \mathrm{mL}$, whereas the $\mathrm{MBC}$ values ranged from 0.28 to $135 \mu \mathrm{g} / \mathrm{mL}$. In addition, essential oil of Australian-grown Ocimum tenuiflorum (Tulsi) showed antibacterial activity against selected microbial pathogens including methicillin-resistant S. aureus (MRSA), E. coli, and $P$. aeruginosa with $\mathrm{MIC}$ values ranging from 2.25 to
$>4.5 \mu \mathrm{g} / \mathrm{mL}$ [125]. The essential oil of Pogostemon cablin was shown to have effective antibacterial activity against many pathogenic bacterial strains including E. coli, S. aureus, K. pneumoniae, and $H$. pylori [1, 60-64]. The GC-MS analysis of essential oils of Foeniculum vulgare (Fennel) showed the occurrence of trans-anethole, methylchavicol, limonene, and fenchone, whereas Cuminum cyminum L. had $\gamma$-terpin-7al, $\gamma$-terpinene, $\beta$-pinene, and cuminaldehyde as the major constituents. Both essential oils were effective against $S$. typhimurium and E. coli [28]. The F. vulgare oil exhibited the lowest MIC values of 0.062 and $0.031 \%(\mathrm{v} / \mathrm{v})$ against $E$. coli and $S$. typhimurium, respectively, whereas C. cyminum oil showed MIC values of 0.250 and $0.125 \%(\mathrm{v} / \mathrm{v})$ against $E$. coli and $S$. typhimurium, respectively. The bacterial strains $S$. aureus, $B$. cereus, and $P$. aeruginosa were strongly inhibited by the essential oil of Warionia saharae, which contained $\beta$ eudesmol, trans-nerolidol, linalool, 1,8-cineole, camphor, $p$ cymene, and terpinen-4-ol as major compounds [79]. The MICs ranged between 0.039 and $0.156 \mathrm{mg} / \mathrm{mL}$ for all tested bacterial strains. The essential oil extracted from seeds of Trachyspermum ammi showed activity against all 36 clinical isolates of K. pneumoniae, E. coli, and S. aureus isolated from patients suffering from urinary tract infections [74]. An MIC value of $250 \mathrm{ppm}$ was observed for $K$. pneumoniae, whereas it was observed to be $100 \mathrm{ppm}$ for E. coli and S. aureus. The seed essential oils of Nigella sativa containing thymoquinone, $p$-cymene, $\alpha$-thujene, thymohydroquinone, and longifolene as major phytocompounds were shown to exhibit strong antibacterial activity against $B$. cereus, E. coli, P. aeruginosa, and $S$. aureus. The oil was highly effective against $B$. cereus, $B$. subtilis, and $S$. aureus and showed a complete zone of inhibition at $3000 \mathrm{ppm}$ concentration. Moreover, the zones of inhibition for P. aeruginosa and E. coli were 20 and $25 \mathrm{~mm}$, respectively [126]. A study by Cui et al. [69] has shown that Salvia sclarea oil showed a considerable inhibitory potential against the growth of E. coli, S. aureus, Bacillus pumilus, $K$. pneumoniae, B. subtilis, S. typhimurium, and P. aeruginosa with MIC and MBC of 0.05 and $0.1 \%$, respectively. Ahmadi et al. [77] reported the antibacterial properties of Thymus kotschyanus essential oil against B. cereus, E. coli, S. aureus, and S. epidermidis. The MIC values for these pathogens ranged from 0.097 to $6.25 \mu \mathrm{L} / \mathrm{mL}$. The antibacterial activity of Euphrasia rostkoviana essential oil against E. faecalis, E. coli, K. pneumoniae, S. aureus, S. epidermidis, and $P$. aeruginosa was reported by Novy et al. [35]. In the study, all Gram-positive bacteria were effectively inhibited with an MIC of $512 \mu \mathrm{g} / \mathrm{mL}$. The bacterial strain S. epidermidis was inhibited by the essential oils of Plectranthus barbatus and $P$. amboinicus with an MIC value of $31 \mu \mathrm{g} / \mathrm{mL}[4,33]$. Likewise, the essential oil of Plectranthus neochilus was shown to inhibit some cariogenic bacteria such as E. faecalis, $S$. salivarius, Streptococcus sobrinus, Streptococcus sanguinis, $S$. mitis, S. mutans, and Lactobacillus casei [59]. The essential oil displayed moderate antibacterial activity against $E$. faecalis $(\mathrm{MIC}=250 \mu \mathrm{g} / \mathrm{mL})$ and $S$. salivarius $(\mathrm{MIC}=250 \mu \mathrm{g} / \mathrm{mL})$. Meanwhile, S. sobrinus (MIC $=62.5 \mu \mathrm{g} / \mathrm{mL}$ ), S. sanguinis $(\mathrm{MIC}=62.5 \mu \mathrm{g} / \mathrm{mL})$, S. mitis $(\mathrm{MIC}=31.25 \mu \mathrm{g} / \mathrm{mL})$, and Lactobacillus casei (MIC $=31.25 \mu \mathrm{g} / \mathrm{mL}$ ) were significantly inhibited. Interestingly, the MIC value for S. mutans was 
found to be $3.9 \mu \mathrm{g} / \mathrm{mL}$. In another study, the essential oil of Fortunella margarita was shown to inhibit Streptococcus faecalis and $P$. aeruginosa significantly with inhibitory zones of $30 \mathrm{~mm}$ and $28 \mathrm{~mm}$, respectively. In addition, moderate activity was observed for B. subtilis, S. aureus, Sarcina lutea, and E. coli with inhibitory zones ranging from 20 to $25 \mathrm{~mm}$ [36]. Similarly, Achillea fragrantissima essential oil was effective against $S$. aureus, $S$. epidermidis, and $E$. coli with the highest inhibition zone of $26 \mathrm{~mm}, 16 \mathrm{~mm}$, and $16 \mathrm{~mm}$, respectively [19]. In a study by Radaelli et al. [127], a major food-borne disease-causing agent, C. perfringens, was inhibited by essential oils of Brazilian MAPs such as basil, rosemary, marjoram, peppermint, thyme, and Pimpinella anisum (anise). The MIC values were $1.25 \mathrm{mg} / \mathrm{mL}$ for thyme, $5.0 \mathrm{mg} / \mathrm{mL}$ for marjoram and basil, and $10 \mathrm{mg} / \mathrm{mL}$ for peppermint, rosemary, and anise. Mahmoud et al. [128] have shown the antimicrobial potential of 11 essential oils against all the tested microbes (S. aureus, E. coli, P. aeruginosa, and K. pneumoniae). Onion oil exhibited good antibacterial activity (MIC $=12 \mu \mathrm{g} / \mathrm{mL})$ against $S$. aureus. Chamomile (Anthemis nobilis) oil showed the best activity against $P$. aeruginosa $(\mathrm{MIC}=5.1 \mu \mathrm{g} / \mathrm{mL})$. Origanum and chamomile oils showed the highest antibacterial activity (MIC 7.2, 7.5, and $7.7 \mu \mathrm{g} / \mathrm{mL}$ ) against E. coli. Origanum and ivy (Dolichos lablab) oils were effective against K. pneumoniae with MIC values of 6.2 and $6.5 \mu \mathrm{g} / \mathrm{mL}$, respectively. More recent studies have revealed that essential oils of Eucalyptus globulus, Matricaria chamomilla, Termitomyces schimperi, and $R$. officinalis possess antimicrobial activity against $S$. aureus, S. pyogenes, S. typhi, Shigella spp., E. coli, and $P$. aeruginosa [129]. The essential oil of Termitomyces schimperi showed MIC values of $<15.75 \mathrm{mg} / \mathrm{mL}$ for most of the tested bacteria, whereas other essential oils exhibited MIC values of $15.75-36.33 \mathrm{mg} / \mathrm{mL}$ against tested bacteria.

3.2. Antifungal Effects of Essential Oils. The essential oils and their constituents have been used against a broad range of fungal pathogens. Table 2 summarizes various essential oils, their chemical compositions, and their antifungal activity against human pathogens. The essentials oils extracts from many plants such as basil, citrus, fennel, lemon grass, oregano, rosemary, and thyme have shown considerable antifungal activity against a wide range of fungal pathogens [65]. Arora and Kaur [120] observed the antimicrobial activity of essential oils extracted from spices against fungal pathogens. They found that garlic and clove extracts inhibited the growth of Candida acutus, C. albicans, C. apicola, C. catenulata. C. inconspicua, C. tropicalis, Rhodotorula rubra, Saccharomyces cerevisiae, and Trigonopsis variabilis. Similarly, Grohs and Kunz [29] investigated mixtures of ground spices and demonstrated their efficacy against the C. lipolytica. According to the report of Ultee and Smid [55], oregano and thyme essential oils were some of the best inhibitors of fungal pathogens, because of the phenolic compounds (carvacrol and thymol) as main constituents, which disrupt fungal cell membranes. Likewise, Delaquis and Mazza [130] reported the antimicrobial effects of isothiocyanate isolated from the essential oils of onion and garlic plants. They stated that isothiocyanates may inactivate the extracellular enzymes through oxidative cleavage of disulfide bonds. Isothiocyanate was effective against Botrytis, Fusarium, Penicillium, and Cladosporium species. The antifungal activity of essential oils and their derivatives on the cell viability, mycelium growth, and mycotoxin-producing ability of molds has been studied [131]. It was concluded that, among all the tested essential oils, clove, cinnamon, and oregano essential oils were effective against Aspergillus parasiticus and Fusarium moniliforme. The oil of Origanum vulgare was efficient at inhibiting C. albicans, Aspergillus niger, Microsporum gypseum, Microsporum canis, Arthroderma cajetani, Trichophyton violaceum, Trichophyton mentagrophytes, Epidermophyton floccosum, T. rubrum, and Trichophyton tonsurans $[52,56]$. The MIC values ranged from 0.625 to $10.0 \mathrm{mg} / \mathrm{mL}$ against all the tested microbes. The essential oils of Lippia sidoides, Rosmarinus officinalis, Salvia sclarea, and Momordica charantia were shown to inhibit $C$. albicans effectively [39, 44, 65]. Clove essential oil showed an MIC value of 0.125 and $0.062 \%(\mathrm{v} / \mathrm{v})$ against C. albicans and $A$. niger, respectively. Rosemary essential oil exhibited MIC values of 0.25 and $1.0 \%(\mathrm{v} / \mathrm{v})$ against $C$. albicans and A. niger, respectively [65]. Thymol and carvacrol effectively inhibited C. albicans with inhibition zones of 10.6 and $9 \mathrm{~mm}$, respectively [39].

Similarly, Jirovetz et al. [70] analyzed the antifungal activity of Coriandrum sativum oil against Candida species. The essential oil obtained from leaves and flowers of the Ocimum sp. showed considerable antifungal potential against C. albicans, C. tropicalis, C. glabrata, Penicillium notatum, Rhizopus stolonifer, and Mucor mucedo [27, 47, 48]. Likewise, Myrtus communis oil also inhibited C. albicans, Aspergillus flavus, and Fusarium culmorum [45, 85, 86]. The essential oils of thyme and clove completely inhibited the mycelial growth of $A$. flavus when $3 \mu \mathrm{L}$ of oil was added to the Petri-dish [86]. The MIC values of $M$. communis oil were found to be $50 \mu \mathrm{L} / \mathrm{mL}$ for $A$. flavus and $30 \mu \mathrm{L} / \mathrm{mL}$ for $A$. ochraceus and F. culmorum [45]. In addition, Bouzabata et al. [87] analyzed the antifungal activity of $M$. communis oil against E. floccosum, Microsporum canis, Trichophyton rubrum (dermatophytes), and Cryptococcus neoformans (yeast). An MIC value of $0.64 \mathrm{mg} / \mathrm{mL}$ was found to be lethal for M. canis, T. rubrum, and E. floccosum. However, Candida sp. and Aspergillus sp. strains were relatively less inhibited, with MIC values of $1.25 \mathrm{mg} / \mathrm{mL}$ and $5 \mathrm{mg} / \mathrm{mL}$, respectively. Tea tree oil (Melaleuca alternifolia) was effective against many fungal pathogens such as Alternaria spp., A. flavus, A. fumigates, A. niger, Blastoschizomyces capitatus, $C$. albicans, C. glabrata, C. parapsilosis, C. tropicalis, Cladosporium spp., Cryptococcus neoformans, E. floccosum, Fusarium spp., Malassezia furfur, Malassezia sympodialis, Microsporum canis, M. gypseum, Penicillium spp., Rhodotorula rubra, S. cerevisiae, T. mentagrophytes, T. rubrum, T. tonsurans, and Trichosporon sp. [81]. The essential oil of Salvia sclarea, a medicinal plant, contained $56.88 \%$ linalyl acetate, $20.75 \%$ linalool, $5.08 \%$ germacrene $\mathrm{D}$, and $3.41 \% \beta$-caryophyllene as the chief chemical compounds. The essential oil and the pure compounds (linalyl acetate and linalool) were shown to possess antifungal properties against C. albicans, C. tropicalis, C. krusei, C. glabrata, and C. parapsilosis [84]. The antifungal activity of Pogostemon cablin oil against Aspergillus species and $C$. albicans has been reported by many authors $[1,90,91]$. 
MIC values of $0.064 \mathrm{mg} / \mathrm{mL}$ (cinnamon oil) and $0.032 \mathrm{mg} / \mathrm{mL}$ (pogostemon oil) for C. albicans, $0.129 \mathrm{mg} / \mathrm{mL}$ (cinnamon oil) and $0.064 \mathrm{mg} / \mathrm{mL}$ (pogostemon oil) for C. tropicalis, and $0.129 \mathrm{mg} / \mathrm{mL}$ (cinnamon oil) and $0.064 \mathrm{mg} / \mathrm{mL}$ (pogostemon oil) for C. krusei were observed [90]. The essential oils of Mentha pulegium and M. suaveolens were efficient at inhibiting fungal species such as S. cerevisiae, Kloeckera apiculata, Candida zemplinina, Metschnikowia pulcherrima, and Tetrapisispora phaffi [41]. The essential oil of M. insularis showed the highest activity against Staphylococcus xylosus with an MIC value of $3.6 \mu \mathrm{L} / \mathrm{mL}$. Moreover, Venturi et al. [82] reported the antifungal action of the essential oils extracted from Glechon spathulata and G. marifolia against the dermatophytic fungi Trichophyton rubrum and Epidermophyton floccosum. The MIC values ranged from 10 to $83 \mathrm{mg} / \mathrm{mL}$ against $T$. rubrum and 83 to $500 \mathrm{mg} / \mathrm{mL}$ against $E$. floccosum. The essential oil of Daucus littoralis was effective against $C$. albicans with the MIC value ranging from 20 to $40 \mu \mathrm{L} / \mathrm{mL}$ [80]. Seed essential oil of Nigella sativa was shown to possess activity against $A$. flavus, F. moniliforme, Fusarium graminearum, and Penicillium viridicatum [46]. This oil was very effective and showed up to $90 \%$ zone inhibition against $F$. moniliforme. Moreover, the dermatophytic fungus T. rubrum was repressed by the essential oil of J. excelsa and the MIC value was observed to be $128 \mathrm{mg} / \mathrm{mL}$ [38].

More recently, eugenol (an essential oil compound from clove) was shown to cause permanent damage to the cells of C. albicans and was considered to be an efficient antifungal agent. The MIC value of eugenol was found to be $1.0 \% \mathrm{v} / \mathrm{v}$ [92]. Beatovic et al. [57] have reported its antifungal potential against Ocimum basilicum, Aspergillus ochraceus, A. versicolor, A. niger, A. fumigates, Trichoderma viride, and P. funiculosum. Similarly, the inhibitory potential of Aegle marmelos oil against $C$. albicans, $A$. niger, and $F$. oxysporum was demonstrated. The essential oils extracted from Eremanthus erythropappus, $P$. barbatus, and $P$. amboinicus were shown to inhibit the growth of C. albicans, Cryptococcus gattii, Cryptococcus neoformans, and S. cerevisiae [33]. Papajani et al. [88] have reported the antifungal activity of rosemary essential oil against dermatophytes such as A. cajetani, E. floccosum, M. gypseum, M. canis, T. violaceum, T. mentagrophytes, T. rubrum, and T. tonsurans and phytopathogens such as Botrytis cinerea and Pleomorphomonas oryzae. According to them, concentration below $20 \mu \mathrm{g} / \mathrm{mL}$ was not effective and they suggested the use of concentrations above $100 \mu \mathrm{g} / \mathrm{ml}$ for better antifungal activity. The essential oil of Fortunella margarita exhibited activity against $A$. niger and C. albicans with a zone of inhibition of more than $30 \mathrm{~mm}$ [36]. In a recent study by Souza et al. [89], the essential oil of Pelargonium graveolens showed effective inhibitory potential against $C$. tropicalis, a pathogen resistant to clinically used antifungal agents. The essential oil of $P$. graveolens was found to be rich in geraniol and linalool. Four common essential oils of MAPs including litsea (Litsea cubeba), oregano, marjoram (Origanum majorana L.), thymus, and their mixtures showed varied levels of antifungal activity against $C$. albicans, $C$. tropicalis, C. krusei, C. guilliermondii, C. parapsilosis, and $S$. cerevisiae [132]. More recently, the essential oils obtained from E. globulus, M. chamomilla, T. schimperi, and $R$. officinalis demonstrated effective antifungal activity against Trichophyton spp. and Aspergillus spp. [129].

3.3. Antiviral Effects of Essential Oils. Plant-based products and bioactive pure compounds may be a new source of antiviral drugs, as natural products have inherently high chemical diversity. Viral diseases are still a major problem for human health worldwide. So far, only a limited number of drugs are effective against many of these viruses, which has prompted research into finding new antiviral lead molecules. From our literature survey, it is evident that many essential oils possess antiviral properties against many DNA and RNA viruses, such as herpes simplex virus type 1 (HSV-1) and type 2 (HSV-2), dengue virus type 2, Junin virus, influenza virus adenovirus type 3 , poliovirus, and coxsackievirus B1 $[96,105,114,133,134]$.

The antiviral activities of essential oils of major MAPs along with their constituents are detailed in Table 3. The oregano and clove essential oils also exhibited strong antiviral activity against several nonenveloped RNA and DNA viruses such as adenovirus type 3, poliovirus, and coxsackievirus B1 $[133,134]$. The replication capability of HSV-1 virus could be repressed by various essential oils under in vitro experimental conditions [135-137]. HSV-1 is the cause of common viral infections in humans, such as herpetic keratitis, herpetic encephalitis, mucocutaneous herpes infections, and neonatal herpes. Studies on the essential oils of Artemisia arborescens, Glechon spathulata, and Glechon marifolia found that they strongly suppressed HSV-1 [82, 93, 138]. Melissa officinalis essential oils have major constituents, namely, citral and citronellal, which could inhibit the replication of HSV-2 [96, 133, 137]. Likewise, the antiherpes activities of Australian tea tree oil, eucalyptus oil, and thyme oil have been previously reported [93, 135-138]. The major chemical constituent $\alpha$ caryophyllene, which occurs in many essential oils of medicinal plants, is considered to be the best antiviral agent [135].

Likewise, several phenylpropanoids and sesquiterpenes including eugenol, trans-anethole, $\beta$-eudesmol, $\beta$-caryophyllene, and farnesol, which are present in essential oils, also have antiviral properties against HSV [135]. Similarly, another major compound of essential oils, eugenol, showed virucidal activity against human herpesvirus [137, 139]. Some triterpenes and sesquiterpenes also possess antiviral activity against different herpesviruses and rhinovirus [140-143]. García et al. [144] reported the antiviral activity of Artemisia douglasiana and Eupatorium patens essential oils against the dengue virus. In addition, Lippia junelliana and Lippia turbinate essential oils showed activity against the Junin virus. Anti-influenza A (H2N2) activity was exhibited by the essential oil compounds of Pogostemon cablin [1, 97-99] and the antiviral property of the essential oils obtained from fruits and leaves of Fortunella margarita exhibited potential activity against avian influenza A virus (H5N1) [94]. Roy et al. [100] indicated the potential antiviral activity of Trachyspermum ammi oil against Japanese encephalitis virus (JEV). Similarly, Zeedan et al. [19] reported the antiviral activity of Achillea fragrantissima against the ORF virus (a parapox virus). More recently, Pourghanbari et al. [145] evaluated in vitro antiviral activity of $M$. officinalis (lemon balm) essential oil and 
oseltamivir and their synergistic effect on avian influenza virus (AIV) subtype H9N2. They found that various concentrations of lemon balm essential oil suppressed influenza virus replication. However, it had improved efficacy when coadministered with the antiviral agent oseltamivir. Essential oils obtained from Colombian MAPs such as Lepechinia salviifolia, Minthostachys mollis, Hyptis mutabilis, Lepechinia vulcanicola, and Ocimum campechianum were reported to possess antiviral activity against human herpes viruses types 1 and 2 [95]. They also reported that these essential oils inhibit viral activity during their early stages of infection. Thus, plant-based essential oils could be used as antiviral agents against several viral diseases in humans and have the potential to be used as alternatives to synthetic antiviral drugs.

\section{Mechanism of Antimicrobial Action of Essential Oils against Human Pathogens}

MAPs contain several types of chemical constituents that have antimicrobial properties. These are synthesized to protect the plants from microbial pathogens. The antimicrobial properties of essential oils mainly depend on their chemical constituents and the quantity of the major single compounds [15]. These chemical compounds are secreted through a series of molecular interactions under specific biotic/abiotic stress conditions $[15,146]$. Each compound may exhibit a different mechanism of action against microbes. Overall, the mechanism of antibacterial action is mediated by a series of biochemical reactions in the bacterial cell, which are dependent on the type of chemical constituents present in the essential oil $[15,110]$. Moreover, the antibacterial activity of essential oils also differs because of different bacterial architecture, such as Gram-positive and Gram-negative bacteria, which differ in their cell membrane compositions $[83,114]$. In the following sections, the mechanism of antimicrobial activities of essential oils is described with reference to the available literature. The possible antimicrobial actions of essential oils are illustrated in Figure 2.

4.1. Action against Bacterial Pathogens. Various mechanisms of antibacterial activity of essential oils have been proposed. Essential oils primarily destabilize the cellular architecture, leading to the breakdown of membrane integrity and increased permeability, which disrupts many cellular activities, including energy production (membrane-coupled), membrane transport, and other metabolic regulatory functions. The disruption of the cell membrane by essential oils may assist various vital processes such as energy conversion processes, nutrient processing, the synthesis of structural macromolecules, and the secretion of growth regulators [66]. The essential oils may affect both the external envelope of the cell and the cytoplasm $[15,114]$. Owing to their lipophilic nature, essential oils are easily penetrable through the bacterial cell membranes. Essential oils of various MAPs were reported to cause increased bacterial cell membrane permeability leading to the leakage of cellular components and loss of ions $[66,114,147]$. The antibacterial effect of essential oils is also linked to reduced membrane potentials, the disruption of proton pumps, and the depletion of the ATP [148]. This alteration in the cell organization may cause a cascade effect, resulting in other cell organelles being affected [43]. Likewise, Cox et al. $[149,150]$ have demonstrated that tea tree oil inhibits the growth of $S$. aureus and E. coli by altering cell permeability, increasing the leakage of intracellular $\mathrm{K}+$ ions and disturbing cell respiration. The essential oils pass through the cell wall and cytoplasmic membrane, which may disrupt the arrangement of dissimilar fatty acids, phospholipids bilayers, and polysaccharides molecules [114, 147, 151]. All these events may be responsible for the coagulation of inner cellular components in the cytoplasm and break down of the bonds between the lipid and protein layers [110].

In some cases, the pure compounds of essential oils exhibit higher antibacterial activity compared to the essential oil. The antibacterial effect of essential oil constituents such as thymol, menthol, and linalyl acetate is because of a perturbation of the lipid fractions of bacterial plasma membranes [152]. This may affect the permeability of the membrane and induce leakage of intracellular materials. Carvacrol is a hydrophobic compound that influences cell membranes by altering the composition of fatty acids, which then affects the membrane fluidity and permeability [16]. However, its exact mechanism of action is still unclear. It was reported that carvacrol significantly depleted the internal ATP pool of bacterial cells $[16,153]$. In another study, carvacrol induced the leakage and loss of ATP from bacterial cells [154]. Likewise, the compounds methyl carvacrol, menthol, citronellol, and thymol also cause an enlargement of the cell membrane that leads to passive diffusion of ions between the expanded phospholipids [16, 147, 153, 154]. Another effect of essential oils on cell membranes is the inhibition of toxin secretion. Ultee and Smid [55] reported that exposure of B. cereus to carvacrol resulted in the inhibition of toxin production, and application of oregano essential oil completely abolished the enterotoxin production of $S$. aureus. Thus, the secretion of toxins may be prevented by modifications in the bacterial membrane due to the influence of the essential oil compounds on the transmembrane transport process in the plasma membrane, which limits the release of toxins to the external environment [155]. Another mechanism of action is by trans-cinnamaldehyde, which enters the periplasm of the cell and disrupts cellular functions $[16,156]$. Moreover, $p$-cymene has a greater affinity towards bacterial cell membranes and thus may disturb the membrane integrity $[16,157]$. The outer membrane proteins are also affected by essential oil components. For example, carvacrol can disturb the insertion and folding of proteins such as DnaK and GroEL $[16,110]$. Carvacrol can also inhibit the synthesis of flagellin, a microbial protein required for bacterial motility [16]. The phenylpropene, eugenol, also exhibits activity by modifying the fatty acid outline to alter the cytoplasmic membrane of different bacteria. In addition, it can destroy various bacterial enzymes such as ATPase, amylase, histidine carboxylase, and proteases $[158,159]$. Likewise, cinnamaldehyde was reported to inhibit ATPase enzymes and disrupt the outer cell membrane [160]. Other studies have found that vanillin exhibited antimicrobial activity by obstructing the pathways of bacterial respiration and disrupting the flux of $\mathrm{K}+$ ions and $\mathrm{pH}$ gradient [161]. Similarly, 


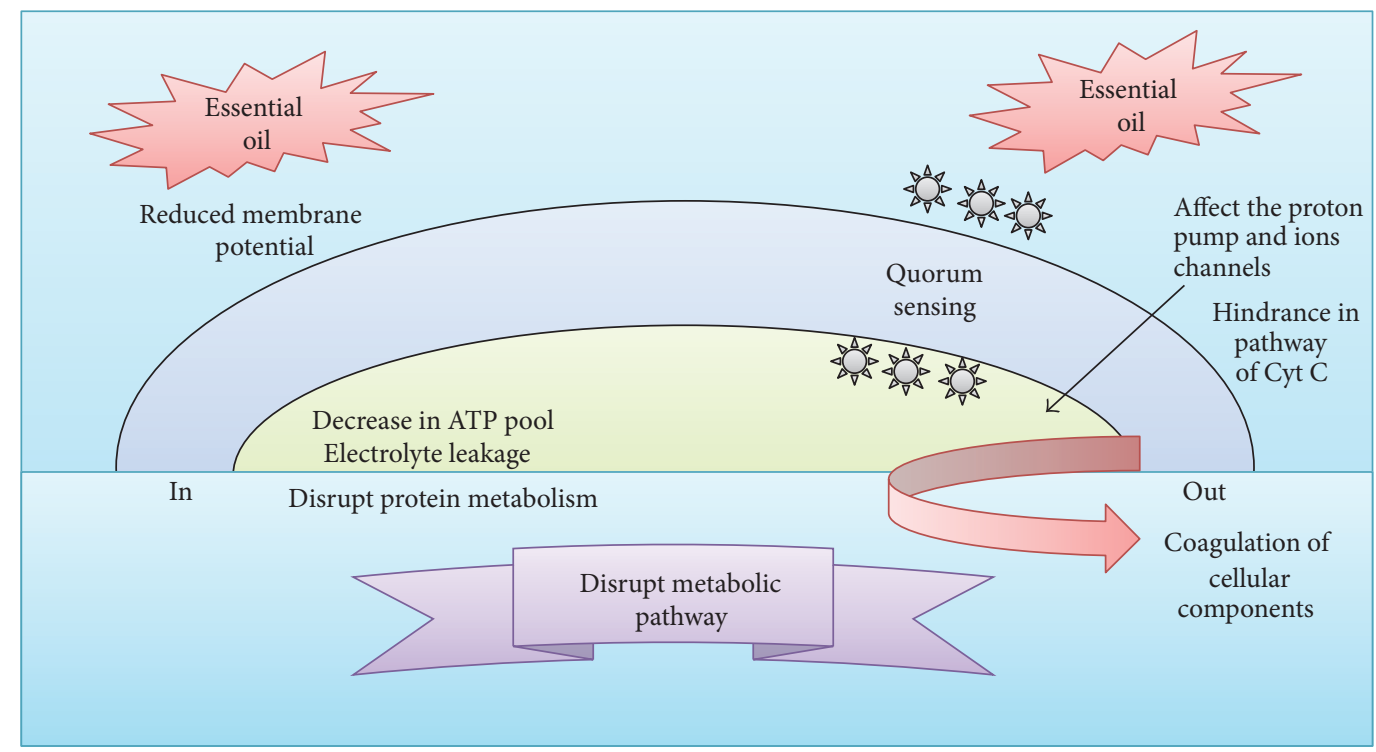

Figure 2: Antimicrobial mechanisms of essential oils on microbes.

carveol, citronellal, and carvone essential oils were shown to modify hydrophobicity and disrupt membrane integrity, leading to the leakage of $\mathrm{K}^{+}$ions [162]. Some essential oils can inhibit the cell-cell communication quorum sensing network mediated by various bacterial signal molecules [163]. The efficacy of the antibacterial effect of essential oils or their individual compounds may differ from one microbe to another. Hence, elucidation on the exact mechanisms of action of each essential oil and their components is required, including further study on the numerous microbial strains/species. Furthermore, detailed study on the components of essential oils would be helpful to improve our understanding of their mechanism of antimicrobial activity.

4.2. Action against the Fungal Pathogens. The antifungal actions of essential oils are similar to that of previously explained antibacterial mechanisms. Generally, exposure of essential oils leads to the coagulation of the cellular components because of irreversible cell membrane damage. In yeast cells, essential oils establish a membrane potential across the cell membrane and disrupt the production of ATP, which leads to cell membrane damage [85]. The essential oils have the ability to penetrate and disrupt the fungal cell wall and cytoplasmic membranes through a permeabilization process, which leads to the disintegration of mitochondrial membranes. This is caused by alterations in the flow of electrons inside the electron transport system (ETS) pathway. This may also damage the lipids, proteins, and nucleic acid contents of cells infected by the fungal pathogens [164]. The essential oils could also disrupt the depolarization of the mitochondrial membranes by affecting ions channels, especially $\mathrm{Ca}^{2+}$ ions, proton pumps, and ATP pools, and therefore decrease the membrane potential. This change in the fluidity of membranes may cause electrolyte leakage and hinder cytochrome $\mathrm{C}$ pathways, proteins metabolism, and calcium ion concentrations. Therefore, the permeabilization of inner and outer mitochondrial membranes may result in the cell apoptosis or necrosis leading to cell death [165].

4.3. Actions against the Viruses. At present, various essential oils may be a promising alternative against viral infections [105]. However, the detailed understanding on the antiviral action of essential oils still requires more research. Some of the reported mechanisms of action of essential oils are reported in this section. Essential oils might interfere with virion envelopment, designed for entry into host cells. For instance, the sesquiterpene triptofordin C-2 was reported to suppress the synthesis of viral proteins and inhibit the early gene expression process of the HSV-1 virus [141]. Schnitzler et al. [135] investigated the antiviral activity of star anise essential oil as well as compounds such as eugenol, trans-anethole, farnesol, $\beta$-eudesmol, $\beta$-caryophyllene, and $\beta$-caryophyllene oxide against HSV-1. They found the direct inactivation of HSV-1 particles, which is also reported in another study where eugenol was used [141]. Moreover, eugenol directly inactivates the growth of the herpes virus [139], whereas isoborneol (monoterpene) affected the glycosylation process of viral proteins, which inhibited the growth of HSV-1 [166]. Similarly, essential oils of ginger, thyme, hyssop, and sandalwood were able to inhibit acyclovir-resistant HSV-1 [136]. Possible mechanisms of action include the inhibition of virus replication by hindering cellular DNA polymerase and alteration in phenylpropanoid pathways. Furthermore, sesquiterpenes are known to inhibit cytomegalovirus (CMV) early gene expression [142]. According to Pourghanbari et al. [145], the essential oil of lemon balm inhibits influenza virus replication at different replication cycles by directly interacting with the virus particles.

\section{Conclusion and Future Prospects}

The essential oils extracted from various MAPs possess strong antimicrobial activity against various bacterial, fungal, and 
viral pathogens. The reactivity of essential oils depends upon the nature of their functional groups and orientation. Essential oils are considered to be potent against a diverse range of pathogens. Essential oils may disrupt the cell membrane of the targeted pathogens by increasing membrane permeability, inducing leakage of vital intracellular constituents, and interrupting the cellular metabolism and enzyme kinetics of the targeted pathogens. The present study reveals more information on in vitro research studies of essential oils; however, more efforts are required to conduct clinical trials in the future. Most of these antimicrobial studies using essential oils have failed to provide definite information on their chemical nature as well as their mechanisms of action. This poses ambiguity on the reproducibility and accuracy of their discoveries. Therefore, further research should focus on exploring the molecular mechanisms of essential oils and their individual chemical compounds. Biopharmaceutical industries are in need of ecofriendly alternative drug molecules to treat diseases associated with microbial pathogens and body metabolism. Thus, essential oils of MAPs might be a prospective source of alternative antimicrobial agents and may play an important role in the discovery of new drugs for the treatment of a wide range of pathogenic microorganisms in the near future.

\section{Competing Interests}

The authors declare that there is no conflict of interests.

\section{Acknowledgments}

The authors are highly grateful to the Department of Crop Science, Universiti Putra Malaysia, Malaysia, for providing research facilities.

\section{References}

[1] M. K. Swamy and U. R. Sinniah, "A comprehensive review on the phytochemical constituents and pharmacological activities of Pogostemon cablin Benth.: an aromatic medicinal plant of industrial importance," Molecules, vol. 20, no. 5, pp. 8521-8547, 2015.

[2] M. Kumara Swamy, K. M. Sudipta, P. Lokesh et al., "Phytochemical screening and in vitro antimicrobial activity of Bougainvillea spectabilis flower extracts," International Journal of Phytomedicine, vol. 4, no. 3, pp. 375-379, 2012.

[3] M. S. Akhtar, B. Degaga, and T. Azam, "Antimicrobial activity of essential oils extracted from medicinal plants against the pathogenic microorganisms: a review," Biological Sciences and Pharmaceutical Research, vol. 2, no. 1, pp. 1-7, 2014.

[4] G. Arumugam, M. K. Swamy, and U. R. Sinniah, "Plectranthus amboinicus (Lour.) Spreng: botanical, phytochemical, pharmacological and nutritional significance," Molecules, vol. 21, no. 4, p. 369, 2016.

[5] R. Bhattacharya, K. R. C. Reddy, and A. K. Mishra, "Export strategy of Ayurvedic products from India," International Journal of Ayurvedic Medicine, vol. 5, no. 1, pp. 125-128, 2014.

[6] M. K. Swamy and U. R. Sinniah, "Patchouli (Pogostemon cablin Benth.): botany, agrotechnology and biotechnological aspects," Industrial Crops and Products, vol. 87, pp. 161-176, 2016.
[7] J. Degenhardt, T. G. Köllner, and J. Gershenzon, "Monoterpene and sesquiterpene synthases and the origin of terpene skeletal diversity in plants," Phytochemistry, vol. 70, no. 15-16, pp. 16211637, 2009.

[8] M. K. Swamy, S. K. Mohanty, U. R. Sinniah, and A. Maniyam, "Evaluation of Patchouli (Pogostemon cablin Benth.) cultivars for growth, yield and quality parameters," Journal of Essential Oil Bearing Plants, vol. 18, no. 4, pp. 826-832, 2015.

[9] B. Ali, N. A. Al-Wabel, S. Shams, A. Ahamad, S. A. Khan, and F. Anwar, "Essential oils used in aromatherapy: a systemic review," Asian Pacific Journal of Tropical Biomedicine, vol. 5, no. 8, pp. 601-611, 2015.

[10] C. B. Duschatzky, M. L. Possetto, L. B. Talarico et al., "Evaluation of chemical and antiviral properties of essential oils from South American plants," Antiviral Chemistry and Chemotherapy, vol. 16, no. 4, pp. 247-251, 2005.

[11] A. Al-Mariri and M. Safi, "In vitro antibacterial activity of several plant extracts and oils against some gram-negative bacteria," Iranian Journal of Medical Sciences, vol. 39, no. 1, pp. 36-43, 2014.

[12] K. A. Hammer, C. F. Carson, and T. V. Riley, "Antimicrobial activity of essential oils and other plant extracts," Journal of Applied Microbiology, vol. 86, no. 6, pp. 985-990, 1999.

[13] G. Lang and G. Buchbauer, "A review on recent research results (2008-2010) on essential oils as antimicrobials and antifungals. A review," Flavour and Fragrance Journal, vol. 27, no. 1, pp. 13-39, 2012.

[14] A. Koroch, H. R. Juliani, and J. A. Zygadlo, "Bioactivity of essential oils and their components," in Flavours and Fragrances Chemistry, Bioprocessing and Sustainability, R. G. Berger, Ed., pp. 87-115, Springer, Berlin, Germany, 2007.

[15] F. Nazzaro, F. Fratianni, L. De Martino, R. Coppola, and V. De Feo, "Effect of essential oils on pathogenic bacteria," Pharmaceuticals, vol. 6, no. 12, pp. 1451-1474, 2013.

[16] G. R. Rudramurthy, M. K. Swamy, U. R. Sinniah, and A. Ghasemzadeh, "Nanoparticles: alternatives against drug-resistant pathogenic microbes," Molecules, vol. 21, no. 7, p. 836, 2016.

[17] S. Mulyaningsih, F. Sporer, S. Zimmermann, J. Reichling, and M. Wink, "Synergistic properties of the terpenoids aromadendrene and 1,8-cineole from the essential oil of Eucalyptus globulus against antibiotic-susceptible and antibiotic-resistant pathogens," Phytomedicine, vol. 17, no. 13, pp. 1061-1066, 2010.

[18] M. Skočibušić, N. Bezić, V. Dunkić, and A. Radonić, "Antibacterial activity of Achillea clavennae essential oil against respiratory tract pathogens," Fitoterapia, vol. 75, no. 7-8, pp. 733-736, 2004.

[19] G. S. G. Zeedan, A. M. Abdalhamed, M. E. Ottai, S. Abdelshafy, and E. Abdeen, "Antimicrobial, antiviral activity and GC-MS analysis of essential oil extracted from Achillea fragrantissima plant growing in Sinai Peninsula, Egypt," Journal of Microbiology and Biochemical Technology, vol. 8, article 006, 2014.

[20] F. Maggi, M. Bramucci, C. Cecchini et al., "Composition and biological activity of essential oil of Achillea ligustica All. (Asteraceae) naturalized in central Italy: ideal candidate for anti-cariogenic formulations," Fitoterapia, vol. 80, no. 6, pp. 313319, 2009.

[21] D. Lopes-Lutz, D. S. Alviano, C. S. Alviano, and P. P. Kolodziejczyk, "Screening of chemical composition, antimicrobial and antioxidant activities of Artemisia essential oils," Phytochemistry, vol. 69, no. 8, pp. 1732-1738, 2008.

[22] B. Teixeira, A. Marques, C. Ramos et al., "Chemical composition and antibacterial and antioxidant properties of commercial 
essential oils," Industrial Crops and Products, vol. 43, no. 1, pp. 587-595, 2013.

[23] J. R. Hood, J. M. Wilkinson, and H. M. A. Cavanagh, "Evaluation of common antibacterial screening methods utilized in essential oil research," Journal of Essential Oil Research, vol. 15, no. 6, pp. 428-433, 2003.

[24] M. Unlu, E. Ergene, G. V. Unlu, H. S. Zeytinoglu, and N. Vural, "Composition, antimicrobial activity and in vitro cytotoxicity of essential oil from Cinnamomum zeylanicum Blume (Lauraceae)," Food and Chemical Toxicology, vol. 48, no. 11, pp. 32743280, 2010.

[25] B. F. M. T. Andrade, L. N. Barbosa, I. S. Probst, and A. F. Júnior, "Antimicrobial activity of essential oils," Journal of Essential Oil Research, vol. 26, no. 1, pp. 34-40, 2014.

[26] J. C. Matasyoh, Z. C. Maiyo, R. M. Ngure, and R. Chepkorir, "Chemical composition and antimicrobial activity of the essential oil of Coriandrum sativum," Food Chemistry, vol. 113, no. 2, pp. 526-529, 2009.

[27] A. F. Begnami, M. C. T. Duarte, V. Furletti, and V. L. G. Rehder, "Antimicrobial potential of Coriandrum sativum L. against different Candida species in vitro," Food Chemistry, vol. 118, no. 1, pp. 74-77, 2010.

[28] D. S. Bisht, K. R. K. Menon, and M. K. Singhal, "Comparative antimicrobial activity of essential oils of Cuminum cyminum L. and Foeniculum vulgare Mill. seeds against Salmonella typhimurium and Escherichia coli," Journal of Essential Oil-Bearing Plants, vol. 17, no. 4, pp. 617-622, 2014.

[29] B.-M. Grohs and B. Kunz, "Use of spice mixtures for the stabilisation of fresh portioned pork," Food Control, vol. 11, no. 6, pp. 433-436, 2000.

[30] A. Ait-Ouazzou, S. Lorán, A. Arakrak et al., "Evaluation of the chemical composition and antimicrobial activity of Mentha pulegium, Juniperus phoenicea, and Cyperus longus essential oils from Morocco," Food Research International, vol. 45, no. 1, pp. 313-319, 2012.

[31] F. Yousefbeyk, A. R. Gohari, M. H. S. Sourmaghi et al., "Chemical composition and antimicrobial activity of essential oils from different parts of Daucus littoralis Smith subsp. hyrcanicus Rech. f," Journal of Essential Oil-Bearing Plants, vol. 17, no. 4, pp. 570-576, 2014.

[32] B. L. Saet, H. C. Kwang, N. K. Su et al., "The antimicrobial activity of essential oil from Dracocephalum foetidum against pathogenic microorganisms," Journal of Microbiology, vol. 45, no. 1, pp. 53-57, 2007.

[33] N. O. Dos Santos, B. Mariane, J. H. G. Lago et al., "Assessing the chemical composition and antimicrobial activity of essential oils from Brazilian plants-Eremanthus erythropappus (Asteraceae), Plectrantuns barbatus, and P. amboinicus (Lamiaceae)," Molecules, vol. 20, no. 5, pp. 8440-8452, 2015.

[34] K. Chaieb, H. Hajlaoui, T. Zmantar et al., "The chemical composition and biological activity of clove essential oil, Eugenia caryophyllata (Syzigium aromaticum L. Myrtaceae): a short review," Phytotherapy Research, vol. 21, no. 6, pp. 501-506, 2007.

[35] P. Novy, H. Davidova, C. S. Serrano-Rojero, J. Rondevaldova, J. Pulkrabek, and L. Kokoska, "Composition and antimicrobial activity of Euphrasia rostkoviana hayne essential oil," EvidenceBased Complementary and Alternative Medicine, vol. 2015, Article ID 734101, 5 pages, 2015.

[36] N. A. Ibrahim, F. S. El-Sakhawy, M. M. D. Mohammed, M. A. Farid, N. A. M. Abdel-Wahed, and D. A. H. Deabes, "Chemical composition, antimicrobial and antifungal activities of essential oils of the leaves of Aegle marmelos (L.) Correa growing in Egypt," Journal of Applied Pharmaceutical Science, vol. 5, no. 2, pp. 001-005, 2015.

[37] C. R. Flores, A. Pennec, C. Nugier-Chauvin, R. Daniellou, L. Herrera-Estrella, and A.-L. Chauvin, "Chemical composition and antibacterial activity of essential oils extracted from plants cultivated in Mexico," Journal of the Mexican Chemical Society, vol. 58, no. 4, pp. 452-455, 2014.

[38] M. Khoury, M. El Beyrouthy, N. Ouaini, M. Iriti, V. Eparvier, and D. Stien, "Chemical composition and antimicrobial activity of the essential oil of Juniperus excelsa M. Bieb. growing wild in Lebanon," Chemistry and Biodiversity, vol. 11, no. 5, pp. 825-830, 2014.

[39] M. A. Botelho, N. A. P. Nogueira, G. M. Bastos et al., "Antimicrobial activity of the essential oil from Lippia sidoides, carvacrol and thymol against oral pathogens," Brazilian Journal of Medical and Biological Research, vol. 40, no. 3, pp. 349-356, 2007.

[40] M. D. Soković, J. Vukojević, P. D. Marin, D. D. Brkić, V. Vajs, and L. J. L. D. Van Griensven, "Chemical composition of essential oils of Thymus and Mentha species and their antifungal activities," Molecules, vol. 14, no. 1, pp. 238-249, 2009.

[41] G. L. Petretto, F. Fancello, S. Zara et al., "Antimicrobial activity against beneficial microorganisms and chemical composition of essential oil of Mentha suaveolens ssp. insularis grown in Sardinia," Journal of Food Science, vol. 79, no. 3, pp. M369-M377, 2014.

[42] K. A. Hammer, C. F. Carson, and T. V. Rileya, "Effects of Melaleuca alternifolia (tea tree) essential oil and the major monoterpene component terpinen-4-ol on the development of single- and multistep antibiotic resistance and antimicrobial susceptibility", Antimicrobial Agents and Chemotherapy, vol. 56, no. 2, pp. 909-915, 2012.

[43] C. F. Carson, B. J. Mee, and T. V. Riley, "Mechanism of action of Melaleuca alternifolia (tea tree) oil on Staphylococcus aureus determined by time-kill, lysis, leakage, and salt tolerance assays and electron microscopy," Antimicrobial Agents and Chemotherapy, vol. 46, no. 6, pp. 1914-1920, 2002.

[44] A. Braca, T. Siciliano, M. D’Arrigo, and M. P. Germanò, "Chemical composition and antimicrobial activity of Momordica charantia seed essential oil," Fitoterapia, vol. 79, no. 2, pp. 123-125, 2008.

[45] B. Berka-Zougali, M.-A. Ferhat, A. Hassani, F. Chemat, and K. S. Allaf, "Comparative study of essential oils extracted from Algerian Myrtus communis L. leaves using microwaves and hydrodistillation," International Journal of Molecular Sciences, vol. 13, no. 4, pp. 4673-4695, 2012.

[46] S. Singh, S. S. Das, G. Singh, C. Schuff, M. P. De Lampasona, and C. A. N. Catalán, "Composition, in vitro antioxidant and antimicrobial activities of essential oil and oleoresins obtained from black cumin seeds (Nigella sativa L.)," BioMed Research International, vol. 2014, Article ID 918209, 10 pages, 2014.

[47] D. Runyoro, O. Ngassapa, K. Vagionas, N. Aligiannis, K. Graikou, and I. Chinou, "Chemical composition and antimicrobial activity of the essential oils of four Ocimum species growing in Tanzania," Food Chemistry, vol. 119, no. 1, pp. 311-316, 2010.

[48] O. A. Lawal, I. A. Ogunwande, O. E. Omikorede et al., "Hemical composition and antimicrobial activity of essential oil of Ocimum kilimandscharicum (R. Br.) Guerke: a new chemotype," American Journal of Essential Oils and Natural Products, vol. 2, no. 1, pp. 41-46, 2014.

[49] M. Nevas, A.-R. Korhonen, M. Lindström, P. Turkki, and H. Korkeala, "Antibacterial efficiency of Finnish spice essential 
oils against pathogenic and spoilage bacteria," Journal of Food Protection, vol. 67, no. 1, pp. 199-202, 2004.

[50] P. Peñalver, B. Huerta, C. Borge, R. Astorga, R. Romero, and A. Perea, "Antimicrobial activity of five essential oils against origin strains of the Enterobacteriaceae family," APMIS, vol. 113, no. 1, pp. 1-6, 2005.

[51] S. Santoyo, S. Cavero, L. Jaime, E. Ibañez, F. J. Señoráns, and G. Reglero, "Supercritical carbon dioxide extraction of compounds with antimicrobial activity from Origanum vulgare L.: determination of optimal extraction parameters," Journal of Food Protection, vol. 69, no. 2, pp. 369-375, 2006.

[52] B. Bozin, N. Mimica-Dukic, N. Simin, and G. Anackov, "Characterization of the volatile composition of essential oils of some Lamiaceae spices and the antimicrobial and antioxidant activities of the entire oils," Journal of Agricultural and Food Chemistry, vol. 54, no. 5, pp. 1822-1828, 2006.

[53] S. Amatiste, D. Sagrafoli, G. Giacinti et al., "Antimicrobial activity of essential oils against Staphylococcus aureus in fresh sheep cheese," Italian Journal of Food Safety, vol. 3, no. 3, 2014.

[54] A. Béjaoui, H. Chaabane, M. Jemli, A. Boulila, and M. Boussaid, "Essential oil composition and antibacterial activity of Origanum vulgare subsp. glandulosum Desf. at different phenological stages," Journal of Medicinal Food, vol. 16, no. 12, pp. 11151120, 2013.

[55] A. Ultee and E. J. Smid, "Influence of carvacrol on growth and toxin production by Bacillus cereus," International Journal of Food Microbiology, vol. 64, no. 3, pp. 373-378, 2001.

[56] G. Esen, A. D. Azaz, M. Kurkcuoglu, K. H. C. Baser, and A. Tinmaz, "Essential oil and antimicrobial activity of wild and cultivated Origanum vulgare L. subsp. hirtum (Link) letswaart from the Marmara region, Turkey," Flavour and Fragrance Journal, vol. 22, no. 5, pp. 371-376, 2007.

[57] D. Beatovic, D. Krstic-Miloševic, S. Trifunovic et al., "Chemical composition, antioxidant and antimicrobial activities of the essential oils of twelve Ocimum basilicum L. cultivars grown in Serbia," Records of Natural Products, vol. 9, no. 1, pp. 62-75, 2015.

[58] M. Elgayyar, F. A. Draughon, D. A. Golden, and J. R. Mount, "Antimicrobial activity of essential oils from plants against selected pathogenic and saprophytic microorganisms," Journal of Food Protection, vol. 64, no. 7, pp. 1019-1024, 2001.

[59] E. J. Crevelin, S. C. Caixeta, H. J. Dias et al., "Antimicrobial activity of the essential oil of Plectranthus neochilus against cariogenic bacteria," Evidence-Based Complementary and Alternative Medicine, vol. 2015, Article ID 102317, 6 pages, 2015.

[60] X. Yang, X. Zhang, S.-P. Yang, and W.-Q. Liu, "Evaluation of the antibacterial activity of patchouli oil," Iranian Journal of Pharmaceutical Research, vol. 12, no. 3, pp. 307-316, 2013.

[61] M. Bilcu, A. M. Grumezescu, A. E. Oprea et al., "Efficiency of vanilla, patchouli and ylang ylang essential oils stabilized by iron oxide@C14 nanostructures against bacterial adherence and biofilms formed by Staphylococcus aureus and Klebsiella pneumoniae clinical strains," Molecules, vol. 19, no. 11, pp. 1794317956, 2014.

[62] C. Pullagummi, N. B. Rao, B. C. S. Singh et al., "Comparitive studies on antibacterial activity of Patchouli [Pogostemon cablin (Blanco) Benth] and Geranium (Pelargonium graveolens) aromatic medicinal plants," African Journal of Biotechnology, vol. 13, no. 23, pp. 2379-2384, 2014.

[63] X.-D. Yu, J.-H. Xie, Y.-H. Wang et al., "Selective antibacterial activity of patchouli alcohol against Helicobacter pylori based on inhibition of urease," Phytotherapy Research, vol. 29, no. 1, pp. 67-72, 2015.
[64] A. Karimi, "Characterization and antimicrobial activity of patchouli essential oil extracted from Pogostemon cablin [Blanco] Benth. [Lamiaceae]," Advances in Environmental Biology, vol. 8, no. 7, pp. 2301-2309, 2014.

[65] Y. Fu, Y. Zu, L. Chen et al., "Antimicrobial activity of clove and rosemary essential oils alone and in combination," Phytotherapy Research, vol. 21, no. 10, pp. 989-994, 2007.

[66] M. Oussalah, S. Caillet, and M. Lacroix, "Mechanism of action of Spanish oregano, Chinese cinnamon, and savory essential oils against cell membranes and walls of Escherichia coli O157:H7 and Listeria monocytogenes," Journal of Food Protection, vol. 69, no. 5, pp. 1046-1055, 2006.

[67] D. Fraternale, L. Giamperi, A. Bucchini et al., "Composition and antifungal activity of essential oil of Salvia sclarea from Italy," Chemistry of Natural Compounds, vol. 41, no. 5, pp. 604-606, 2005.

[68] L. Jirovetz, G. Buchbauer, Z. Denkova, A. Slavchev, A. Stoyanova, and E. Schmidt, "Chemical composition, antimicrobial activities and odor descriptions of various Salvia sp. and Thuja sp. essential oils," Nutrition-Vienna, vol. 30, no. 4, p. 152, 2006.

[69] H. Cui, X. Zhang, H. Zhou, C. Zhao, and L. Lin, "Antimicrobial activity and mechanisms of Salvia sclarea essential oil," Botanical Studies, vol. 56, no. 1, pp. 1-8, 2015.

[70] L. Jirovetz, K. Wlcek, G. Buchbauer et al., "Antifungal activities of essential oils of salvia lavandulifolia, salvia officinalis and salvia sclarea against various pathogenic Candida species," Journal of Essential Oil-Bearing Plants, vol. 10, no. 5, pp. 430439, 2007.

[71] F. Oke, B. Aslim, S. Ozturk, and S. Altundag, "Essential oil composition, antimicrobial and antioxidant activities of Satureja cuneifolia Ten." Food Chemistry, vol. 112, no. 4, pp. 874-879, 2009.

[72] L. S. Kasim, K. O. Olaleye, A. B. Fagbohun, S. F. Ibitoye, and O. E. Adejumo, "Chemical composition and antibacterial activity of essential oils from Struchium sparganophora Linn. ktze asteraceae," Advances in Biological Chemistry, vol. 4, no. 4, pp. 246-252, 2014.

[73] A. A. Mohamed, S. I. Ali, and F. K. El-Baz, "Antioxidant and antibacterial activities of crude extracts and essential oils of Syzygium cumini Leaves," PLoS ONE, vol. 8, no. 4, Article ID e60269, 2013.

[74] M. Hassanshahian, Z. Bayat, S. Saeidi, and Y. Shiri, "Antimicrobial activity of Trachyspermum ammi essential oil against human bacterial," International Journal of Biomedical and Advance Research, vol. 2, no. 1, pp. 18-24, 2014.

[75] B. Imelouane, H. Amhamdi, J. P. Wathelet, M. Ankit, K. Khedid, and A. El Bachiri, "Chemical composition and antimicrobial activity of essential oil of thyme (Thymus vulgaris) from eastern Morocco," International Journal of Agriculture and Biology, vol. 11, no. 2, pp. 205-208, 2009.

[76] D. F. Santurio, F. P. K. de Jesus, R. A. Zanette, K. B. Schlemmer, A. Fraton, and L. L. M. Fries, "Antimicrobial activity of the essential oil of thyme and of thymol against Escherichia coli strains," Acta Scientiae Veterinariae, vol. 42, no. 1, pp. 1-4, 2014.

[77] R. Ahmadi, A. Alizadeh, and S. Ketabchi, "Antimicrobial activity of the essential oil of Thymus kotschyanus grown wild in Iran," International Journal of Biosciences, vol. 6, no. 3, pp. 239248, 2015.

[78] B. Shan, Y.-Z. Cai, J. D. Brooks, and H. Corke, "Potential application of spice and herb extracts as natural preservatives in cheese," Journal of Medicinal Food, vol. 14, no. 3, pp. 284-290, 2011. 
[79] K. Sellam, M. Ramchoun, F. Khalouki, C. Alem, and L. ElRhaffari, "Biological investigations of antioxidant, antimicrobial properties and chemical composition of essential oil from Warionia saharae," Oxidants and Antioxidants in Medical Science, vol. 3, no. 1, pp. 73-78, 2014.

[80] F. Yousefbeyk, A. R. Gohari, M. H. S. Sourmaghi et al., "Chemical composition and antimicrobial activity of essential oils from different parts of Daucus littoralis Smith subsp. hyrcanicus Rech. F," Journal of Essential Oil-Bearing Plants, vol. 17, no. 4, pp. 570-576, 2014.

[81] K. A. Hammer, C. F. Carson, and T. V. Riley, "In vitro activity of Melaleuca alternifolia (tea tree) oil against dermatophytes and other filamentous fungi," Journal of Antimicrobial Chemother$a p y$, vol. 50, no. 2, pp. 195-199, 2002.

[82] C. R. Venturi, L. J. Danielli, F. Klein et al., "Chemical analysis and in vitro antiviral and antifungal activities of essential oils from Glechon spathulata and Glechon marifolia," Pharmaceutical Biology, vol. 53, no. 5, pp. 682-688, 2015.

[83] K. A. Hammer and C. F. Carson, "Antibacterial and antifungal activities of essential oils," in Lipids and Essential Oils as Antimicrobial Agents, H. Thormar, Ed., pp. 255-306, John Wiley \& Sons, London, UK, 2011.

[84] Y. Hristova, V. Gochev, J. Wanner et al., "Chemical composition and antifungal activity of essential oil of Salvia sclarea L. from Bulgaria against clinical isolates of Candida species," Journal of Bioscience and Biotechnology, vol. 2, no. 1, pp. 39-44, 2013.

[85] V. Aleksic and P. Knezevic, "Antimicrobial and antioxidative activity of extracts and essential oils of Myrtus communis L.," Microbiological Research, vol. 169, no. 4, pp. 240-254, 2014.

[86] R. Omidbaigi, M. Yahyazadeh, R. Zare, and H. Taheri, “The in vitro action of essential oils on Aspergillus flavus," Journal of Essential Oil-Bearing Plants, vol. 10, no. 1, pp. 46-52, 2007.

[87] A. Bouzabata, C. Cabral, M. J. Gonçalves et al., "Myrtus communis $\mathrm{L}$. as source of a bioactive and safe essential oil," Food and Chemical Toxicology, vol. 75, pp. 166-172, 2015.

[88] V. Papajani, E. Haloci, E. Goci, R. Shkreli, and S. Manfredini, "Evaluation of antifungal activity of Origanum vulgare and Rosmarinus officinalis essential oil before and after inclusion in $\beta$-cyclodextrine," International Journal of Pharmacy and Pharmaceutical Sciences, vol. 7, no. 5, pp. 270-273, 2015.

[89] C. M. C. Souza, S. A. Pereira Junior, T. da Silva Moraes et al., "Antifungal activity of plant-derived essential oils on Candida tropicalis planktonic and biofilms cells," Medical Mycology, vol. 54, no. 5, pp. 515-523, 2016.

[90] G.-S. Wang, J.-H. Deng, Y.-H. Ma, M. Shi, and B. Li, "Mechanisms, clinically curative effects, and antifungal activities of cinnamon oil and pogostemon oil complex against three species of Candida," Journal of Traditional Chinese Medicine, vol. 32, no. 1, pp. 19-24, 2012.

[91] D. Kocevski, M. Du, J. Kan, C. Jing, I. Lačanin, and H. Pavlović, "Antifungal effect of Allium tuberosum, Cinnamomum cassia, and Pogostemon cablin essential oils and their components against population of Aspergillus species," Journal of Food Science, vol. 78, no. 5, pp. M731-M737, 2013.

[92] B. Latifah-Munirah, W. H. Himratul-Aznita, and N. Mohd Zain, "Eugenol, an essential oil of clove, causes disruption to the cell wall of Candida albicans (ATCC 14053)," Frontiers in Life Science, vol. 8, no. 3, pp. 231-240, 2015.

[93] C. Sinico, A. De Logu, F. Lai et al., "Liposomal incorporation of Artemisia arborescens L. essential oil and in vitro antiviral activity," European Journal of Pharmaceutics and Biopharmaceutics, vol. 59, no. 1, pp. 161-168, 2005.
[94] N. A. Ibrahim, S. S. El-Hawary, M. M. D. Mohammed et al., "Chemical composition, antiviral against avian influenza (H5N1) virus and antimicrobial activities of the essential oils of the leaves and fruits of Fortunella margarita, lour. swingle, growing in Egypt," Journal of Applied Pharmaceutical Science, vol. 5, no. 1, pp. 006-012, 2015.

[95] Y. M. Brand, V. C. Roa-Linares, L. A. Betancur-Galvis, D. C. Durán-García, and E. Stashenko, "Antiviral activity of Colombian Labiatae and Verbenaceae family essential oils and monoterpenes on Human Herpes viruses," Journal of Essential Oil Research, vol. 28, no. 2, pp. 130-137, 2016.

[96] A. Allahverdiyev, N. Duran, M. Ozguven, and S. Koltas, "Antiviral activity of the volatile oils of Melissa officinalis L. against Herpes simplex virus type-2," Phytomedicine, vol. 11, no. 7-8, pp. 657-661, 2004.

[97] X.-L. Wu, D.-H. Ju, J. Chen et al., "Immunologic mechanism of patchouli alcohol anti-H1N1 influenza virus may through regulation of the RLH signal pathway in vitro," Current Microbiology, vol. 67, no. 4, pp. 431-436, 2013.

[98] H. Kiyohara, C. Ichino, Y. Kawamura, T. Nagai, N. Sato, and H. Yamada, "Patchouli alcohol: in vitro direct anti-influenza virus sesquiterpene in Pogostemon cablin Benth," Journal of Natural Medicines, vol. 66, no. 1, pp. 55-61, 2012.

[99] H. Wu, B. Li, X. Wang, M. Jin, and G. Wang, "Inhibitory effect and possible mechanism of action of patchouli alcohol against influenza a $\left(\mathrm{H}_{2} \mathrm{~N}_{2}\right)$ virus," Molecules, vol. 16 , no. 8, pp. 64896501, 2011.

[100] S. Roy, P. Chaurvedi, and A. Chowdhary, "Evaluation of antiviral activity of essential oil of Trachyspermum Ammi against Japanese encephalitis virus," Pharmacognosy Research, vol. 7, no. 3, pp. 263-267, 2015.

[101] A. K. Pandey, P. Singh, and N. N. Tripathi, "Chemistry and bioactivities of essential oils of some Ocimum species: an overview," Asian Pacific Journal of Tropical Biomedicine, vol. 4, no. 9, pp. 682-694, 2014.

[102] K. F. Abed, "Antimicrobial activity of essential oils of some medicinal plants from Saudi Arabia," Saudi Journal of Biological Sciences, vol. 14, pp. 53-60, 2007.

[103] F. Bakkali, S. Averbeck, D. Averbeck, and M. Idaomar, "Biological effects of essential oils-a review," Food and Chemical Toxicology, vol. 46, no. 2, pp. 446-475, 2008.

[104] C. Sell, The Chemistry of Fragrances: From Perfumer to Consumer, Royal Society of Chemistry, Cambridge, UK, 2006.

[105] K. Böhme, J. Barros-Velázquez, P. Calo-Mata, and S. P. Aubourg, "Antibacterial, antiviral and antifungal activity of essential oils: mechanisms and applications," in Antimicrobial Compounds, pp. 51-81, Springer, Berlin, Germany, 2014.

[106] M. K. Swamy, U. R. Sinniah, and M. S. Akhtar, "In vitro pharmacological activities and GC-ms analysis of different solvent extracts of Lantana camara leaves collected from tropical region of Malaysia," Evidence-Based Complementary and Alternative Medicine, vol. 2015, Article ID 506413, 9 pages, 2015.

[107] E. Pichersky, J. P. Noel, and N. Dudareva, "Biosynthesis of plant volatiles: nature's diversity and ingenuity," Science, vol. 311, no. 5762, pp. 808-811, 2006.

[108] L. Scorzoni, T. Benaducci, A. M. F. Almeida, D. H. S. Silva, V. D. S. Bolzani, and M. J. S. M. Gianinni, "The use of standard methodology for determination of antifungal activity of natural products against medical yeasts Candida sp and Cryptococcus sp.", Brazilian Journal of Microbiology, vol. 38, no. 3, pp. 391-397, 2007. 
[109] A. Angioni, A. Barra, V. Coroneo, S. Dessi, and P. Cabras, "Chemical composition, seasonal variability, and antifungal activity of Lavandula stoechas L. ssp. stoechas essential oils from stem/leaves and flowers," Journal of Agricultural and Food Chemistry, vol. 54, no. 12, pp. 4364-4370, 2006.

[110] S. Burt, "Essential oils: Their antibacterial properties and potential applications in foods-a review," International Journal of Food Microbiology, vol. 94, no. 3, pp. 223-253, 2004.

[111] M. L. Faleiro, "The mode of antibacterial action of essential oils," in Science Against Microbial Pathogens: Communicating Current Research and Technological Advances, A. Méndez-Vilas, Ed., pp. 1143-1156, Brown Walker Press, Boca Raton, Fla, USA, 2011.

[112] M. A. Calvo, E. L. Arosemena, C. Shiva, and C. Adelantado, "Antimicrobial activity of plant natural extracts and essential oils," in Science Against Microbial Pathogens: Communicating Current Research and Technological Advances, A. Mendez-Vilas, Ed., pp. 1179-1185, Formatex Research Center, Barcelona, Spain, 2012.

[113] M. Lahlou, "Methods to study the phytochemistry and bioactivity of essential oils," Phytotherapy Research, vol. 18, no. 6, pp. 435-448, 2004.

[114] J. S. Raut and S. M. Karuppayil, "A status review on the medicinal properties of essential oils," Industrial Crops and Products, vol. 62, pp. 250-264, 2014.

[115] L. C. de Carvalho Galvão, V. Fernandes Furletti, S. M. Fernandes Bersan et al., "Antimicrobial activity of essential oils against Streptococcus mutans and their antiproliferative effects," Evidence-Based Complementary and Alternative Medicine, vol. 2012, Article ID 751435, 12 pages, 2012.

[116] Conner, "Naturally occurring compounds," in Antimicrobials in Foods, P. M. Davidison and A. L. Branen, Eds., pp. 441-468, Marcel Dekker, New York, NY, USA, 1993.

[117] J. Kim, M. R. Marshall, and C.-I. Wei, "Antibacterial activity of some essential oil components against five foodborne pathogens," Journal of Agricultural and Food Chemistry, vol. 43, no. 11, pp. 2839-2845, 1995.

[118] M. E. Ramos-Nino, M. N. Clifford, and M. R. Adams, "Quantitative structure activity relationship for the effect of benzoic acids, cinnamic acids and benzaldehydes on Listeria monocytogenes," Journal of Applied Bacteriology, vol. 80, no. 3, pp. 303-310, 1996.

[119] B. Ouattara, R. E. Simard, R. A. Holley, G. J.-P. Piette, and A. Bégin, "Antibacterial activity of selected fatty acids and essential oils against six meat spoilage organisms," International Journal of Food Microbiology, vol. 37, no. 2-3, pp. 155-162, 1997.

[120] D. S. Arora and J. Kaur, "Antimicrobial activity of spices," International Journal of Antimicrobial Agents, vol. 12, no. 3, pp. 257-262, 1999.

[121] Y. Sakagami, S. Kaikoh, K. Kajimura, and H. Yokoyama, "Inhibitory effect of clove extract on vero-toxin production by enterohemorrhagic Escherichia coli O157:H7," Biocontrol Science, vol. 5, no. 1, pp. 47-49, 2000.

[122] P. Skandamis, E. Tsigarida, and G.-J. E. Nychas, "The effect of oregano essential oil on survival/death of Salmonella typhimurium in meat stored at $5^{\circ} \mathrm{C}$ under aerobic, VP/MAP conditions," Food Microbiology, vol. 19, no. 1, pp. 97-103, 2002.

[123] S. Zanetti, S. Cannas, P. Molicotti et al., "Evaluation of the antimicrobial properties of the essential oil of Myrtus communis L. against clinical strains of Mycobacterium spp.", Interdisciplinary Perspectives on Infectious Diseases, vol. 2010, Article ID 931530, 3 pages, 2010.
[124] O. A. Lawal, I. A. Ogunwande, O. E. Omikorede et al., "Chemical composition and antimicrobial activity of essential oil of Ocimum kilimandscharicum (R. Br.) Guerke: a new chemotype," American Journal of Essential Oils and Natural Products, vol. 2, no. 1, pp. 41-46, 2014.

[125] H. A. Yamani, E. C. Pang, N. Mantri, and M. A. Deighton, "Antimicrobial activity of Tulsi (Ocimum tenuiflorum) essential oil and their major constituents against three species of bacteria," Frontiers in Microbiology, vol. 7, article 681, 2016.

[126] S. Singh, S. S. Das, G. Singh, C. Schuff, M. P. de Lampasona, and C. A. N. Catalán, "Composition, in vitro antioxidant and antimicrobial activities of essential oil and oleoresins obtained from black cumin seeds (Nigella sativa L.)," BioMed Research International, vol. 2014, Article ID 918209, 10 pages, 2014.

[127] M. Radaelli, B. P. da Silva, L. Weidlich et al., "Antimicrobial activities of six essential oils commonly used as condiments in Brazil against Clostridium perfringens," Brazilian Journal of Microbiology, vol. 47, no. 2, pp. 424-430, 2016.

[128] A. M. Mahmoud, R. M. A. El-Baky, A. B. F. Ahmed, and G. F. M. Gad, "Antibacterial activity of essential oils and in combination with some standard antimicrobials against different pathogens isolated from some clinical specimens," American Journal of Microbiological Research, vol. 4, no. 1, pp. 16-25, 2016.

[129] A. Mekonnen, B. Yitayew, A. Tesema, and S. Taddese, "In vitro antimicrobial activity of essential oil of Thymus schimperi, Matricaria chamomilla, Eucalyptus globulus, and Rosmarinus officinalis," International Journal of Microbiology, vol. 2016, Article ID 9545693, 8 pages, 2016.

[130] P. J. Delaquis and G. Mazza, "Antimicrobial properties of isothiocyanate in food preservation," Food Technology, vol. 49, pp. 73-84, 1995.

[131] S. Juglal, R. Govinden, and B. Odhav, "Spice oils for the control of co-occurring mycotoxin-producing fungi," Journal of Food Protection, vol. 65, no. 4, pp. 683-687, 2002.

[132] V. V. Ebani, S. Nardoni, F. Bertelloni et al., "Antibacterial and antifungal activity of essential oils against some pathogenic bacteria and yeasts shed from poultry," Flavour and Fragrance Journal, vol. 31, no. 4, pp. 302-309, 2016.

[133] J. Reichling, P. Schnitzler, U. Suschke, and R. Saller, "Essential oils of aromatic plants with antibacterial, antifungal, antiviral, and cytotoxic properties-an overview," Forschende Komplementarmedizin, vol. 16, no. 2, pp. 79-90, 2009.

[134] A. J. Wagstaff, D. Faulds, and K. L. Goa, "Aciclovir: a reappraisal of its antiviral activity, pharmacokinetic properties and therapeutic efficacy," Drugs, vol. 47, no. 1, pp. 153-205, 1994.

[135] P. Schnitzler, A. Astani, and J. Reichling, "Screening for antiviral activities of isolated compounds from essential oils," EvidenceBased Complementary and Alternative Medicine, vol. 2011, Article ID 253643, 8 pages, 2011.

[136] P. Schnitzler, K. Schön, and J. Reichling, "Antiviral activity of Australian tea tree oil and eucalyptus oil against herpes simplex virus in cell culture," Pharmazie, vol. 56, no. 4, pp. 343-347, 2001.

[137] C. Koch, J. Reichling, and P. Schnitzler, "Essential oils inhibit the replication of herpes simplex virus type 1 (HSV-1) and type 2 (HSV-2)," in Botanical Medicine in Clinical Practices, V. R. Preedy and R. R. Watson, Eds., pp. 192-197, CABI, Wallingsford, Calif, USA, 2008.

[138] Y. Tragoolpua and A. Jatisatienr, "Anti-herpes simplex virus activities of Eugenia caryophyllus (Spreng.) Bullock \& S. G. Harrison and essential oil, eugenol," Phytotherapy Research, vol. 21, no. 12, pp. 1153-1158, 2007. 
[139] F. Benencia and M. C. Courrges, "In vitro and in vivo activity of eugenol on human herpesvirus," Phytotherapy Research, vol. 14, no. 7, pp. 495-500, 2000.

[140] T. H. J. Niedermeyer, U. Lindequist, R. Mentel et al., "Antiviral terpenoid constituents of Ganoderma pfeifferi," Journal of Natural Products, vol. 68, no. 12, pp. 1728-1731, 2005.

[141] K. Hayashi, T. Hayashi, K. Ujita, and Y. Takaishi, "Characterization of antiviral activity of a sesquiterpene, triptofordin C-2," Journal of Antimicrobial Chemotherapy, vol. 37, no. 4, pp. 759768, 1996.

[142] R. Pusztai, J. Hohmann, D. Rédei, H. Engi, and J. Molnár, "Inhibition of human cytomegalovirus IE gene expression by dihydro- $\beta$-agarofuran sesquiterpenes isolated from Euonymus species," In Vivo, vol. 22, no. 6, pp. 787-792, 2008.

[143] J. M. Rollinger, T. M. Steindl, D. Schuster et al., "Structure-based virtual screening for the discovery of natural inhibitors for human rhinovirus coat protein," Journal of Medicinal Chemistry, vol. 51, no. 4, pp. 842-851, 2008.

[144] C. C. García, L. Talarico, N. Almeida, S. Colombres, C. Duschatzky, and E. B. Damonte, "Virucidal activity of essential oils from aromatic plants of San Luis, Argentina," Phytotherapy Research, vol. 17, no. 9, pp. 1073-1075, 2003.

[145] G. Pourghanbari, H. Nili, A. Moattari, A. Mohammadi, and A. Iraji, "Antiviral activity of the oseltamivir and Melissa officinalis L. essential oil against avian influenza A virus (H9N2)," VirusDisease, vol. 27, no. 2, pp. 170-178, 2016.

[146] R. A. Holley and D. Patel, "Improvement in shelf-life and safety of perishable foods by plant essential oils and smoke antimicrobials," Food Microbiology, vol. 22, no. 4, pp. 273-292, 2005.

[147] N. Y. Saad, C. D. Muller, and A. Lobstein, "Major bioactivities and mechanism of action of essential oils and their components," Flavour and Fragrance Journal, vol. 28, no. 5, pp. 269279, 2013.

[148] A. D. V. Turina, M. V. Nolan, J. A. Zygadlo, and M. A. Perillo, "Natural terpenes: self-assembly and membrane partitioning," Biophysical Chemistry, vol. 122, no. 2, pp. 101-113, 2006.

[149] S. D. Cox, J. E. Gustafson, C. M. Mann et al., "Tea tree oil causes $\mathrm{K}+$ leakage and inhibits respiration in Escherichia coli," Letters in Applied Microbiology, vol. 26, no. 5, pp. 355-358, 1998.

[150] S. D. Cox, C. M. Mann, J. L. Markham et al., "The mode of antimicrobial action of the essential oil of Melaleuca alternifolia (Tea tree oil)," Journal of Applied Microbiology, vol. 88, no. 1, pp. 170-175, 2000.

[151] C. J. Longbottom, C. F. Carson, K. A. Hammer, B. J. Mee, and T. V. Riley, "Tolerance of Pseudomonas aeruginosa to Melaleuca alternifolia (tea tree) oil is associated with the outer membrane and energy-dependent cellular processes," Journal of Antimicrobial Chemotherapy, vol. 54, no. 2, pp. 386-392, 2004.

[152] D. Trombetta, F. Castelli, M. G. Sarpietro et al., "Mechanisms of antibacterial action of three monoterpenes," Antimicrobial Agents and Chemotherapy, vol. 49, no. 6, pp. 2474-2478, 2005.

[153] A. Ultee, E. P. W. Kets, and E. J. Smid, "Mechanisms of action of carvacrol on the food-borne pathogen Bacillus cereus," Applied and Environmental Microbiology, vol. 65, no. 10, pp. 4606-4610, 1999.

[154] A. Ultee, M. H. J. Bennik, and R. Moezelaar, "The phenolic hydroxyl group of carvacrol is essential for action against the food-borne pathogen Bacillus cereus," Applied and Environmental Microbiology, vol. 68, no. 4, pp. 1561-1568, 2002.

[155] E. L. de Souza, J. C. de Barros, C. E. V. de Oliveira, and M. L. da Conceição, "Influence of Origanum vulgare L. essential oil on enterotoxin production, membrane permeability and surface characteristics of Staphylococcus aureus," International Journal of Food Microbiology, vol. 137, no. 2-3, pp. 308-311, 2010.

[156] I. M. Helander, H.-L. Alakomi, K. Latva-Kala et al., "Characterization of the action of selected essential oil components on Gram-negative bacteria," Journal of Agricultural and Food Chemistry, vol. 46, no. 9, pp. 3590-3595, 1998.

[157] M. Cristani, M. D’Arrigo, G. Mandalari et al., "Interaction of four monoterpenes contained in essential oils with model membranes: implications for their antibacterial activity," Journal of Agricultural and Food Chemistry, vol. 55, no. 15, pp. 6300-6308, 2007.

[158] J. Thoroski, "Eugenol induced inhibition of extracellular enzyme production by Bacillus cereus," Journal of Food Protection, vol. 52, pp. 399-403, 1989.

[159] K. P. Devi, S. A. Nisha, R. Sakthivel, and S. K. Pandian, "Eugenol (an essential oil of clove) acts as an antibacterial agent against Salmonella typhi by disrupting the cellular membrane," Journal of Ethnopharmacology, vol. 130, no. 1, pp. 107-115, 2010.

[160] C. N. Wendakoon and M. Sakaguchi, "Inhibition of amino acid decarboxylase activity of Enterobacter aerogenes by active components in spices," Journal of Food Protection, vol. 58, pp. 280-283, 1995.

[161] D. J. Fitzgerald, M. Stratford, M. J. Gasson et al., "Mode of antimicrobial action of vanillin against Escherichia coli, Lactobacillus plantarum and Listeria innocua," Journal of Applied Microbiology, vol. 97, no. 1, pp. 104-113, 2004.

[162] J. C. Lopez-Romero, H. González-Ríos, A. Borges, and M. Simões, "Antibacterial effects and mode of action of selected essential oils components against Escherichia coli and Staphylococcus aureus," Evidence-Based Complementary and Alternative Medicine, vol. 2015, Article ID 795435, 9 pages, 2015.

[163] M. Á. Szabó, G. Z. Varga, J. Hohmann et al., "Inhibition of quorum-sensing signals by essential oils," Phytotherapy Research, vol. 24, no. 5, pp. 782-786, 2010.

[164] B. Arnal-Schnebelen, F. Hadji-Minaglou, J.-F. Peroteau, F. Ribeyre, and V. G. De Billerbeck, "Essential oils in infectious gynaecological disease: a statistical study of 658 cases," International Journal of Aromatherapy, vol. 14, no. 4, pp. 192-197, 2004.

[165] H. S. Yoon, S. C. Moon, N. D. Kim, B. S. Park, M. H. Jeong, and Y. H. Yoo, "Genistein induces apoptosis of RPE-J cells by opening mitochondrial PTP," Biochemical and Biophysical Research Communications, vol. 276, no. 1, pp. 151-156, 2000.

[166] M. Armaka, E. Papanikolaou, A. Sivropoulou, and M. Arsenakis, "Antiviral properties of isoborneol, a potent inhibitor of herpes simplex virus type 1," Antiviral Research, vol. 43, no. 2, pp. 79-92, 1999. 


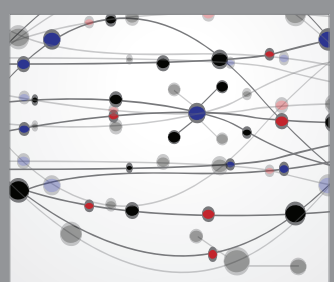

The Scientific World Journal
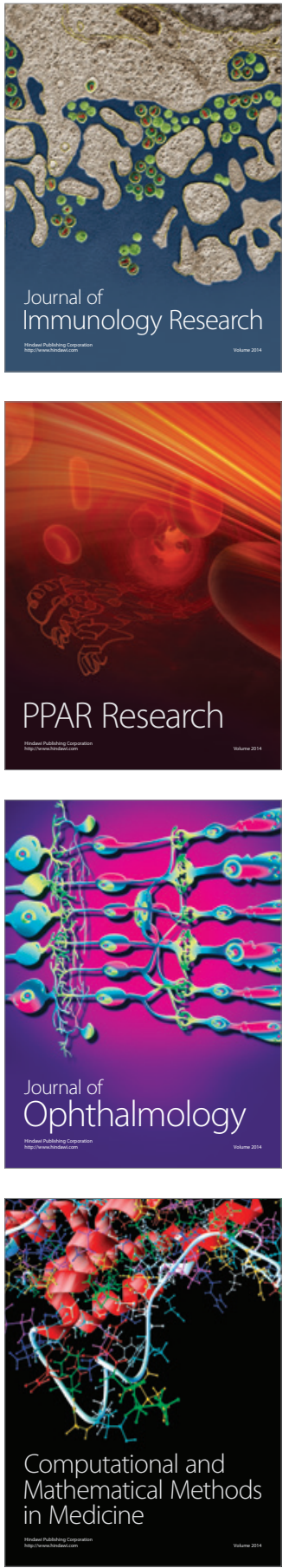

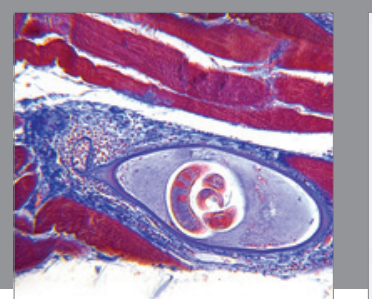

Gastroenterology Research and Practice

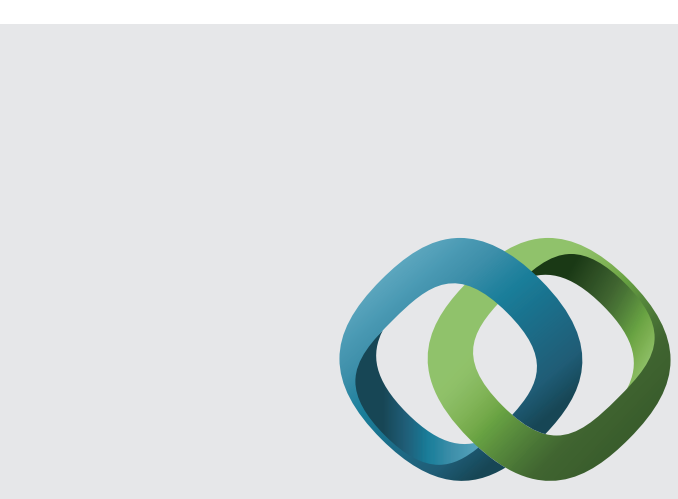

\section{Hindawi}

Submit your manuscripts at

http://www.hindawi.com
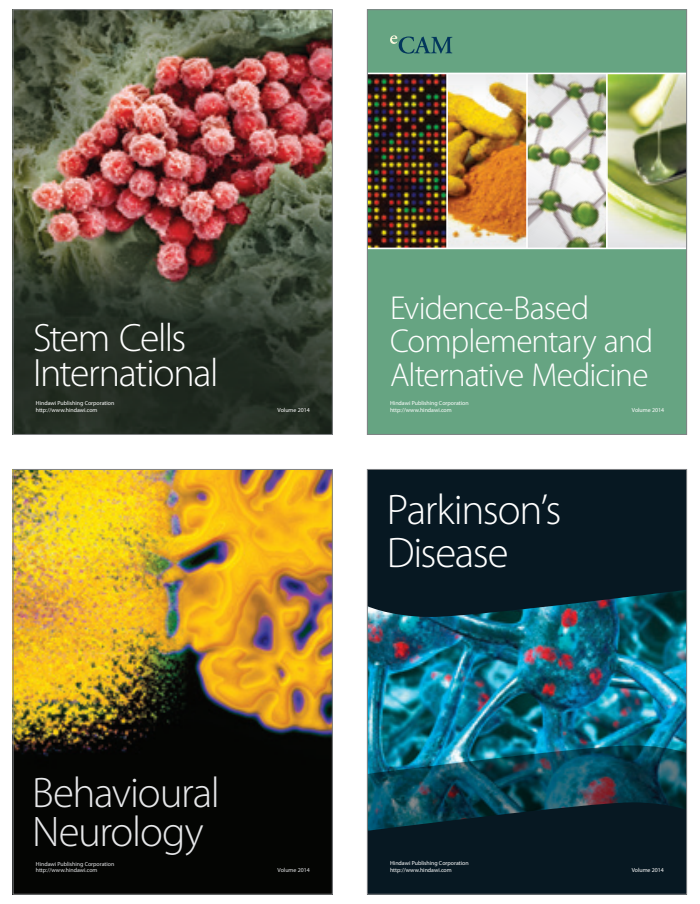
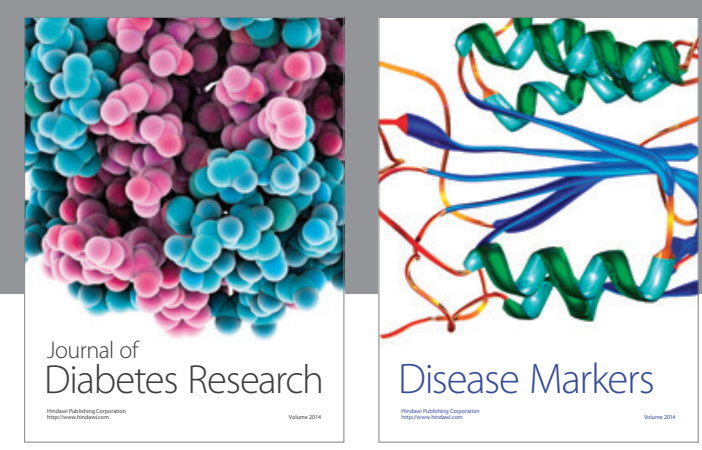

Disease Markers
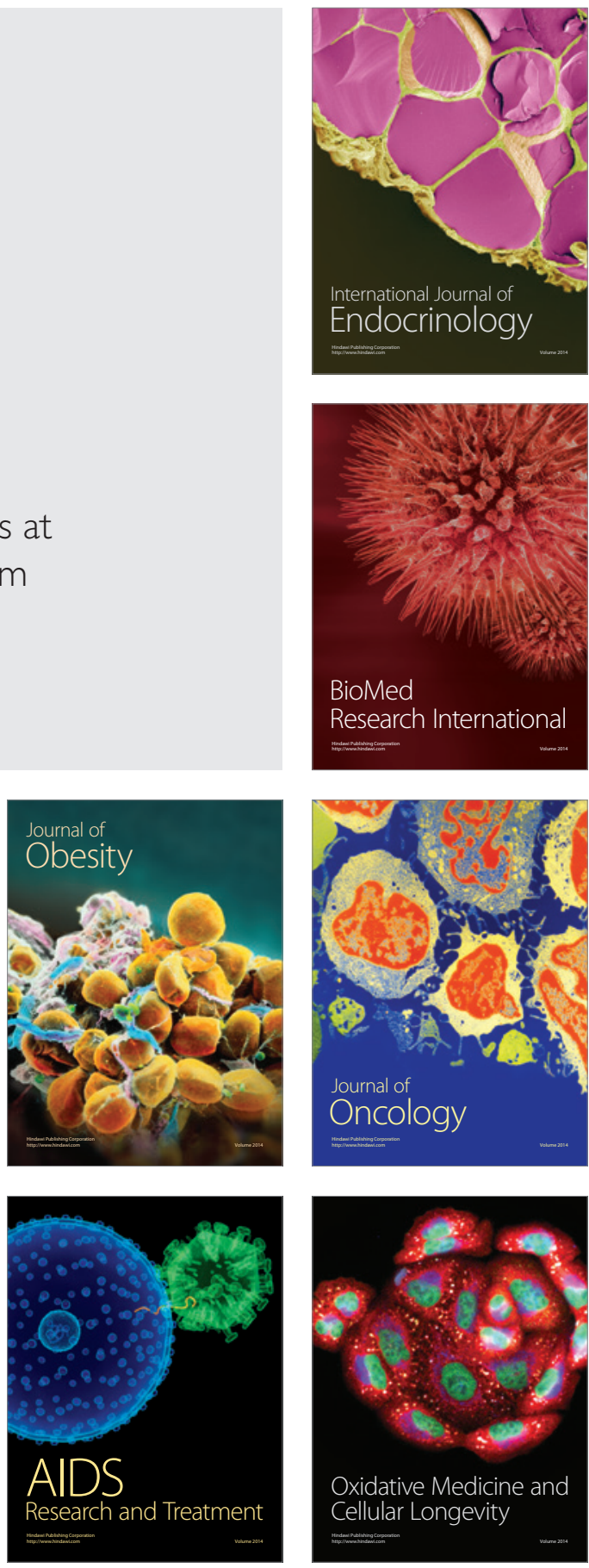